ACO $\quad 1171$ 

Digitized by the Internet Archive in 2007 with funding from Microsoft Corporation 


\section{THE THEORY OF WAGES}


s.s. 


\section{THE}

\section{THEORY OF WAGES}

\section{AND ITS APPLICATION}

TO

THE EIGHT HOURS QUESTION AND

OTHER LABOUR PROBLEMS

BY

HERBERT M. THOMPSON, M.A. s.

\section{迧anoan}

MACMILLAN AND CO.

AND NEW YORK

1892 


\section{PREFACE}

WE are not likely to deal with wages questions in the best way if we have no grasp of the general theory of the subject. If we are groping in the dark we shall not estimate aright the probable amount of effects from given causes, perhaps not even their direction.

The matter deserves attention even from the general public, for few are unconcerned with it directly or indirectly. To diminish the haziness of view which is the dominant characteristic of discussions concerning wages a closer study of the topic than is generally vouchsafed is required. Perhaps the most striking contemporary instance of this necessity is the controversy on the Eight Hours' Question.

But many smaller problems are constantly 
arising in almost everybody's life, and in dealing with these a lack of clearness of view is equally discernible.

For example it may be that we are asked to subscribe to free meals for poor children, and when we have committed ourselves to the subscription list we are rendered uncomfortable by more enlightened philanthropists who tell us that our action will in the long run tend, by the operation of "the iron law of wages," to lower the general rate of wages, so that it appears we are injuring the very people whom we are seeking to benefit. But we take comfort once more when we are informed on still better authority that "the iron law of wages." does not receive acceptance in instructed circles.

If we are to act wisely in these matters we ought not to be at the mercy of stereotyped phrases, or of dicta $e x$ cathedrâ, but we ought ourselves to have some grasp of underlying principles.

If for example we realised that a main cause of poverty was the fact that so very few are working on a high plane of intelligence and skill, compared with the great multitude who are labouring inertly 
on a low one, we should see that the peril of the free breakfasts lay in tranquillising the discontent with the current depressed standard of living amongst the very poor. We should indeed be able to appreciate the contention that the vitality needed for a struggle to a higher plane in the working world is more likely to reside in a little frame that is nourished than in one that is starved. But we should nevertheless see the danger of withdrawing an incentive acting on the parents in a very genuine way and instigating them to accomplish work of a higher calibre, or at least to refrain from acquiescence in employment on a lower level of activity.

True there is no Iron Law in accordance with which wage-earners are, for the same work, always provided with the bare necessaries of life, neither more nor less. At any rate none such exists for wage-earners fully awake to what advantages their position affords, and prepared to claim them to the uttermost.

But nevertheless there is an analogous danger that the lower orders of wage-earners may forge iron fetters for themselves by never striving to 
do a higher grade of work than the lowest which at the moment happens to be the one which will just bring them in the actual necessaries of life.

The idea requires impressing on their minds, that by doing work that is more wanted by the community, they can do much better than provide these bare necessaries for themselves, but that by not striving to do work of any but such a low grade that it is already more than superabundantly provided, even less than the bare necessaries of life may be brought in to the domestic exchequer.

The free breakfast scheme certainly does not enforce this idea, and it is a question whether, in the abiding interests of the wage-earning classes themselves, the severity of the punishment by which the lesson is enforced should be tempered further than mere hurnanity demands by such action as that of the Poor Law.

The following pages do not claim to have a great deal that is original in them, though their arrangement is perhaps new. The economic statements are for the most part those accepted by the economists of to-day, but it has been my aim to put together in a concise form the considerations 
essential to the case scattered through the manuals of Political Economy. This I have endeavoured to do in my first chapter; and in my last I have applied the theory thus expounded to various wageproblems with the view of showing how it can be utilised in grappling with practical questions. These two chapters contain all that is likely to interest the general reader.

There intervene three chapters addressed to economists which it has seemed necessary to embody in order to make my position complete; for, in an attempt to enunciate a wage-theory capable of practical application, it would be inexcusable to run counter to the received economic doctrine of to-day, or even of yesterday, without justifying one's position.

I do not apprehend however that either the second or the third chapter will at the present time encounter any serious dissent. With the fourth chapter the case is different; and it is certainly with some agitation that $I$ have attacked a position lield by a master of Political Economy like Professor Alfred Marshall, who not only himself holds a place in the first rank in the hierarchy of classical 
economists, but is completely versed in contemporary writings, continental and American as well as English.

It was not until after I had written this chapter, that there came into my hands the monograph written by the American economist, Professor J. B. Clark, A.M., "Possibility of a Scientific Law of Wages" (Publications of American Economic Association, vol. iv. No. 1). The supplementary note to that paper contains an argument based on a reductio ad absurdum almost identical with one I have employed, and I confess it is reassuring to me to find that other minds have been working in the same direction as my own.

The theory of wages enunciated in this volume regards the product of industry as being divided up amongst the agents of production in shares all of which are interdependent on each other; consequently the notion that a certain share or certain shares falling to one or more agents of production are fixed, leaving the other shares or share to be enjoyed as a residue of the total product of industry (however great or however small that residue may be), is rejected. The second chapter combats the 
theory that the share of labour is fixed; the third chapter is equally concerned to show that the share of labour is not residuary; the fourth chapter is directed against the commonly received doctrine that rent (the share of land) is merely residuary. No one so far as the present writer knows maintains that the share which goes to make up rent is fixed, or that the shares which go to make up profits and interest respectively are either fixed or residuary. It has therefore not been necessary to devote special chapters to disproving these positions. But the reader will perceive that the ground would not have been rendered clear for the theory which I have tried to propound, without an attempted refutation (1) of the wage-fund theory, (2) of the theory that labour receives the residue of the product of industry after certain fixed deductions for rent, interest, and profits have been made, and (3) that land is in a like residuary position with regard to what is left after fixed deductions have been made for wages, interest, and profits. This must be my excuse for the insertion of three chapters which are I fear not only technical, but also dull (at any 
rate to those who already grant what they seek to prove).

With regard to the last chapter it may perhaps be asked: "What good can result from working out wage-problems in actual concrete numbers, when it is admitted that the figures supplied are purely arbitrary?" My answer is that I have not endeavoured to furnish either statistics or facts. I have confined myself to the attempt to show what statistics and facts are relevant to the case, and the sort of way in which they should be manipulatcd when ascertained. A diminution of the hours of labour for example might result in a higher rate of wages per day as well as per hour, or in a lower rate of wages per hour as well as per day or in a higher rate of wages per hour and a lower rate per day. I have made no attempt to predict what the result of a nine or an eight hours' day at any given time or place would be. I have simply pointed out what it is essential to know before a judgment can be formed of what consequence is probable, and supposing certain stated data, what under those circumstances the effect would be.

As any particular problem which has to be dealt 
with must have its own set of figures and facts, I have preferred simply to portray some few typical cases not with the view of illustrating particular circumstances, but in order to elucidate the kind of investigation and argument that should be entered upon in almost any circumstances.

H. M. T. 



\section{CONTENTS}

\section{CHAPTER I}

PAGE

The Universal Product of Industry and Abstinence (the "Universal Dividend" as it might be called) is a mass of wealth varying in amonnt, and divided in varying proportions amongst the agents to its production-

$\S 1$. What the Universal Dividend is. It is to be noted that it is a VARYING produet . . . . . . 1

§2. There are an infinite number of contributories to the Universal Dividend, but we may distinguish four main elasses, in one of which each will find itself included, vir.. :-
(1) Laboutr,
(2) Organising power,
(3) Use of Capital,
(4) Use of Land, Rivers, ete.

Amongst the providers of these four the varying product of industry is divided . . . .

$\S 3$. The division amongst the several agents of production follows the play of supply and demand. It is therefore further to be noted that the share of the product allotted to any one agent of production is itself a VARYING PROPORTION of that varying produet. If any agent of prodnction increases its contribution to the universal dividend its aggregate reward is almost certainly increased, but its reward if taken in proportion to the service rendered is almost certainly dimin- 
ished. On the comparative importance of these two counteractive variations depends whether a given economic development will or will not be advanta. geous to a given agent of production . .

§4. Observe incidentally that an increase in the units of one of the agents of production sometimes results in a more than proportionate, and sometimes in a less than proportionate, increase in the Universal Dividend. In the former case the Law of Increasing Returns is said to be in operation; in the latter case the Law of Diminishing Returns. A "Unit of Efficiency" defined and exemplified . . . . .

\$5. Danger to the economist of taking account of the increase or diminution of the total product without considering the proportions of its distribution amongst the agents of production ; on on the other hand of paying exclnsive attention to the proportious of that division and being unmindful of the growth or decrease of the total product itself . . . . . . . .

$\S 6$. The theory of wages is a particular application of this general theory of the distribution of wealth. To discover the effect on wages of a given development wo must ascertain

(1) Its effect on the total product,

(2) Its effect on that share of the total prodnct secured by wage.

These two weighed the one against the other will give the effect on aggregate wage ; but if the devclopment involves an alteration in the number of wage-earners, to ascertain the effect on particular wage we must further take account of

(3) The changed relation borne by the aggregate to the particular wage . . . . .

$\S 7$. This Theory of the Distribution of Wealth assumes that the agents of production are all rewarded by varying proportions of a varying product of industry ; that these rewards taken together make up the expenses 
of production; that the expenses of production of commodities are one side of a shield of which the price of commodities is the other; and that consequently price can be ultimately analysed into rewarls secured by agents of production . . . .

$\S 8$. The Theory runs counter to certain doctrines. The next three ehapters are occupied with its defence against these :-

Chapter II. eonsiders the Theory of the Wage-Fund and others logically deduced from it.

Chapter III. considers certain Theories about Profits, Interest, and Rent.

Chapter IV. considers the Theory that Rent does not enter into the Expenses of Production .

$\S 9$. The way is then elear for

Chapter V., which treats wages as one of the varying proportions of a varying product and under this hypothesis considers various labour problems

\section{CHAPTER II}

The Wage-Fund Theory, and the dictum 'A Demand for Commodities is not a Demand for Labour." Detailal examination of examples taken from leading upholders of these theories:-Mill, Fawcett, and Cairnes-

$\$ 10$. Enunciation by Mill of the Wage-Fund theory, according to which wages are determined by a ratio between circulating capital and population . . . .

§11. Professors Walker and Sidgwick have demonstrated that this theory is nntenable, because more efficient labour by the very fact of its greater efficiency, creates an additional fund out of which it will be recouped .

$\$ 12$. The adherents of the old Wagc-Fund theory believed that the average wage for an existent population depended on the existent capital, and since existent capital could be diminished in amount by unproduc- 
tive expenditure, it followed in their view, that unproductive expenditure diminished average wage. But since labour whether employed productively or unproduetively is equally rewarded with wages, if expenditure always resulted in wage-paying, it would make no difference to the wage receiver whether expenditure were productive or unproductive. To reconcile these two positions it was therefore necessary to prove that expenditure does not necessarily result in wagepaying. Hence the doctrine

$A$ Demand for Commoditics is not a Demand for Labour

$\$ 13$. The discrediting of the Wage - Fund theory has not been followed up by the general abandonment of its corollary as so enunciated; hence arises necessity for its detailed examination . . . . . ?

\$14. Rehearsal and criticism of Mill's argument on the subject . . . . . . . .

\$ 15. One of Fawcett's examples examined. The conclusions set forth in the fifth edition of his Manual rehearsed and criticised

$\S 16$. The chapter on the subject in the seventh edition of his Manual . . . . . . . .

$\S 17$. Cairnes's attempt to support the theory by a comparison of the wages paid in the United States with those paid in Great Britain. Criticism . . . .

§ 18. Cairnes's attempt to support the Wage-Fund Theory itself (the parent of the dictum "A Demand for Commodities is not a Demand for Labour") by an historical instance Criticism . . . . . .

\section{CHAPTER III}

Professor F. A. Walker supports the theory that Labour is the residual claimant to the product of industry- 
§ 19. Professor Walker's exposition of his theory that Labour is the residual claimant to the product of industry .

PAGE

\$20. Professor Walker's argument that the residual claimant to the product of industry is the Labourer, is equally applicable to the Entrepreneur, the Capitalist, or the Landlord. His argument used (mutatis mutandis) to show that the Entrepreneur and not the Labourer is the residual claimant. [This he would acknowledge to be absurd.] . . . . . . . .

$\S 21$. The fact is that no one of the claimants to the product of industry can be regarded as residual. Such a view assumes that a change in economic conditions leaves the shares which fall to the other claimants of the product of industry unchanged. This is not the case.

\section{CHAPTER IV}

A Criticism of the Economic Doctrine, that "Rent does not enter into the Expenses of Produetion"-

\$22. Ambignity of the phrase. It may be interpreted to mean "Rent does not form part of the Expenses of Production" or "Rent does nothing towards determining the Expenses of Production." We will in the first place take for examination the former interpretation

\$23. Diagram illustrating the Ricardian theory of Rent. The argument which is founded on it . . .

$\S 24$. The argument fallacious, - for from premises which hold good concerning acres, a conclusion is drawn with regard to bushels of wheat, although by the hypothesis the number of bushels grown per acre is various. . . . . . .

$\S 25$. The diagram reconstructed-taking the efficiency or productive power in the land instead of the area as the unit of land . . . . . . . 
$\S 26$. The diagram again reconstructed-taking land bearing equal produce as the unit; the equal prodnce is the result of an unequal application of capital and labour. The greater the application of these the smaller the rent will be . . . . . . . .

\$27. Passing to the other interpretation of the phrase, viz. :that "Rent does nothing towards determining the Ex. penses of Production" we note the alleged distinction that units of efficiency of capital and labour tend to adjust themselves to the demand, whilst those of land do not. Professor Marshall on this point . .

§ 28. Professor Sorley's enunciation of the doctrine which is controverted in this chapter. He begins by laying down that rent is determined by the price of the product, but glides into a contention that rent forms no part of the product, thus justifying the assertion that economists do not keep the two questions distinct in their minds. His argument examined . . .

$\$ 29$. Contention that rent and prices are mutually determining elements . . . . . . .

$\S 30$. The contrary theory rests on the hypothesis that land is limited, and that its inherent properties are incapable of increase by man's effort. But fertility and accessibility (which are the qualities for which we pay rent) are both capable of increase by man's effort. By man's efforts then a diminution can be caused in rents which will canse a fall in prices of commodities.

§31. Examples of this and of the converse . . . .

§32. The distinction sought to be maintained between the "natural advantages" and the "artificial advantages" of land are untenable, and since capital is convertible into "artificial advantages," rent of land and interest cannot be treated as essentially different in their qualities . . . . . . 
\$33. The Theory of Rent now current legitimately applicable for purposes of comparison between various parcels of land. . But not adequate for the comparison of aggregate rents with the aggregate products of other Agents of Production, for it does not lay down where the margin of cultivation shall be drawn

$\S 34$. The fact that the rent paid by one parcel of land is higher than that paid by another does not show that rent is doing anything towards determining prices. But the fact that rents as a whole may rise or fall in comparison with interest, wages, etc., shows that rents in the aggregate take part in the determination of prices. What is paid for the differences in the inherent efficieney of land does not, but what is paid for the actual inherent efficiency of land in the aggregate does, constitute a determining element in prices

$\$ 35$. Close analogy between land and other agents of production

$\S 36$. Examples

\$37. A "typical commodity" . . . . . .

$\S 38$. Changes in the demands of the community cause changes in the composition of the "typical commodity" .

$\S 39$. This just as true when land is, as when any of the other agents of productions are, concerned . .

$\$ 40$. No more true to say that "rent does not enter into the expenses of production," than that wages, profits, aud interest do not

$\S 41$. Docs the Law of Diminishing Returns affect the case?

$\S 42$. No treatment of the considcration of Land radically different from that of the other Agents of Production is called for on account of the law of Diminishing Returns . . . . . . . .

\$ 43. A tax either on Rents or on Land-Area under cultivation would to a certain extent affect the price of produco from land 
$\S 44$. But if the price paid for commodities is susceptible of being raised by a tax on rents, or on land, that shows that not all the marginal advantage arising from the nse of land goes to the landlord, - a portion of it goes to the consumers of commodities, or in other words the general rate of rents takes its part in determining the prices of commodities . . . . .

\section{CHAPTER V}

Labour is neither limited for its reward to a Wage-Fund, nor is it entitled to the residunem of a varying Product of Industry. Wages (like Rent, Interest, and Entrepreneur's profits) are a Varying Proportion of a Var'tying Produet of Industry. Wages Problems worked out on this basis-

$\$ 45$. The above is in substantial agreement with Professor Marshall's Prineiples of Economics except that Rent is here treated as being on the same basis as Interest, Profits, or Wages . . . . . . . .

COMPARISON OF VARIOUS CIRCUMSTANCES WITI THOSE OF A STANDARD CASE

$\S 46$. Case No. 1. (Imaginary circumstances adopted as a standard of comparison) . $\quad . \quad$. $\quad . \quad$. $\quad$. 82

$\S 47$. Case No. 2. The population doubled . . . . . 83

$\S 48$. The effect on the total product of industry. This dependent on the predominance of the law of diminish. ing returns over that of increasing returns or vice versî. The law of decreasing returns has as its ally the stomach-that of increasing returns, the brain .

$\$ 49$. The effect on the share of the total product of industry

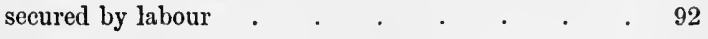

§ 50. Case No. 2 stated . . . . . . . . . 93

$\S 51$. Case No. 3. Population doubled by sudden influx of low-grade, unintelligent Labour . . . 
§ 52. Case No. 4. Population donbled. Edneation and division of labour improved . . . . . . . . $\quad$. 96

§ 53. Case No. 5. Population halved by pestilence . . 98

$\S 54$. Case No. 6. Ireland undẹr changed conditions of cultivation. . . . . .

\$55. Case No. 7. Ireland compelled to adhere to the old state of cultivation, because emigration is impossible

SOME CONTEMPORARY LABOUR PROBLEMS

$\S 56$. Case No. 8. Eight Hours of Labour introdueed .

¿ 57. Case No. 9. An Eight Hours' Movement resulting in a higher wage per eapita, as well as per hour and per unit of Labour Power exerted .

§ 58. Case No. 10. An Eight Hours' Movement resulting in a lower wage per hour, and per unit of Labour Power exerted as well as per capita . . . . .

$\S 59$. The ealeulation of the probable effect of the introduction of an Eight Hours' Day an exceedingly complex problem. This insuffieiently realised by the mass meetings which vote resolutions on the subject

$\S 60$. The assistance rendered to working-men, in coping with economic situations by Trades Unions . . . 114

$\S 61$. Professor Walker on this subject $\quad$. . . . 115

$\S 62$. Condemnation by Professor Walker, by Cairnes, and by Thornton, of the exasperating rules for "making work," ete., of Trades Unions . . . . .

\$63. Trades Unionism on the whole a help rather than a hinirance to perfeet competition . . . . 118

\$ 64. Case No. 11. Labour agrees to combine, and demand a $10 \mathrm{per}$ cent advance on former wage . . . 119

§65. Possible modifications of Case No. 11 . . . . 122 
$\S 66$. Proposal to compel an advance in wages by a labour combination, and simultaneously to prevent any labourers being thrown out of employment by such an all-round reduction of the hours of work, as will necessitate the employment of all the labourers for the due accomplishment of the work required. Data essential to success of such a scheme . . .

§ 67. Case No. 12. Profit-sharing introduced . . . 126

$\S 68$. The extent to which profit-sharing would be introduced by Entrepreneurs under a state of pure competition . . . . . . . .

$\S 69$. Case No. 13. Profit-sharing which does not pay for the Entrepreneur . . . . . . . .

$\S 70$. Case No. 14. The Philanthropic Employer distributes a part of his profits amongst his Employés .

\$71. How far would the employed class be able to compel unwilling employers to adopt such methods as are supposed in Cases Nos. 12, 13, and 14? . .

$\S 72$. "The Iron Law of Wages" inconsistent with the Theory of Wages expounded in these pages, but applicable to some extent to those who do not reap the full advantages of their economic position. The assistance rendered by Trades Unions in enabling labourers to do this . . . . . .

$\$ 73$. Contributions to a wage-earner's pocket constantly incidental to a particular employment, indistinguishable (from his point of view) from the wages of that employment. They consequently are counted as part of wages. Such cases must not be taken as applications of the "Iron Law of Wages" . . 


\section{CHAPTER I}

The Universal Product of Industry and Abstinence, (the "Universal Dividend" as it might be called), is a mass of wealth varying in amount, and divided in varying proportions amongst the agents to its production.

$\S 1$. Professor Alfred Marshall (Principles of Economics, vol. i. book vi. chap. ii. §1) ${ }^{1}$ says :-

1 The references in this book made to Professor Marshall's Principles of Economics are malle to the Second (i.e. to the rearranged) Edition.

For the convenience of those possessing the first edition only who may wish to make reference to the work, the following table shows the corresponding passages as regards the quotations made in these pages :-

\begin{tabular}{|c|c|c|c|c|c|c|}
\hline \multirow{2}{*}{ QUOTED HEREIN. } & \multicolumn{3}{|c|}{ First Edition. } & \multicolumn{3}{|c|}{ Second Edition. } \\
\hline & Book. & Chap. & Section. & Book. & Chap. & Section. \\
\hline Chap. I. \& I & VII. & 3 & 2 & VI. & 2 & 1 \\
\hline Chap. II. \& 13 & VII. & 3 & note & VI. & 2 & note \\
\hline Chap. IV. $\$ 27$ & VII. & 3 & 1 & VI. & $\overline{1}$ & $4-5$ \\
\hline Chap. IV. \$ 27 & VI. & 2 & 3 & V. & 8 & 4 \\
\hline Chap. IV. \& 30 & VI. & 3 & 1 & eli & mina & $t e d$ \\
\hline Chap. IV. \& 30 & VII. & 3 & 3 & VII. & 2 & 2 \\
\hline
\end{tabular}


"The labour and capital of the country, acting on its natural resources, produce annually a certain net aggregate of commodities, material and immaterial, including services of all kinds. This is the true net annual revenue of the country, or as we may say the National Dividend. It is of course unimportant whether we estimate it for a year or for any other period; the important point is that it is a continuous stream always flowing, and not a reservoir or store, or in the narrower sense of the word a 'Fund' of Capital." .. . "This National Dividend is at once the aggregate net product of, and the sole source of payment for, all the agents of production within the country; it is divided up into Earnings of labour, Interest of capital, and lastly the Producer's Surplus, or Rent, of land and of other differential advantages for production. It constitutes the whole of them and the whole of it is distributed among them; and the larger it is, the larger, other things being equal, will be the share of each agent of production."

For our purpose it will be more convenient not to confine our attention to any particular country; if we take the whole world instead of one 
state we shall in just the same way get a product of universal industry and abstinence, a Universal Dividend. This product will vary according to the efforts or abstinences of the various agents of production; the first important point we have to notice is therefore that in the distribution of wealth we have to deal with a Varying Product.

$\S 2$. The agents of production which contribute to make up this varying product are in reality almost infinitely numerous, thus we might distinguish between various grades of labour,--professional labour, artisan labour, unskilled labour, and so forth. As long as it is understood that what holds true amongst the main divisions which may be distinguished amongst the agents of production, will also hold true amongst the minor divisions, they may for simplicity's sake be taken together in a very few large classes which include the smaller classes. Professor Marshall finds it convenient to take three such classes only, viz. labour, capital, and land (including with land "other differential advantages for production"). In the following pages I shall only diverge from this arrangement to the extent of differentiating the entreprencurs' profits from other wages of labour, a distinction which I think it is convenient to maintain. 
The varying product of industry then is divided amongst :-

(1) Wages of labour

(2) Entrepreneurs' profits

(3) Interest on capital and (4) Rent.

$\S 3$. The share of the total product that each agent of production is able to secure for itself depends on the play of supply and demand. It will be remembered by those familiar with the textbooks that an increase in supply of a commodity (except under abnormal circumstances) results in a decrease of price per unit of that commodity,-though probably in an increase of its aggregate price. Supply in the case under consideration must be measured by the amount of effort or abstinence exercised.

Thus if in a given state of things half the product of industry goes to reward labour, an increase of labour power (whether by numerical increase amongst the labourers or otherwise) may be expected, if the other agents of production remain unchanged, to result in labour's securing an additional reward less than the addition made to the total product. Thus each of the agrents of production is rewarded out of the varying product of industry in a proportion which itself varies. These two variations tend to 
some extent to neutralise each other. If for instance we imagine it possible that an increase of population shall take place without changing the contributions to the universal dividend of land, of capital, or of organising power, we shall with the larger number of units of labour obtain a larger product; but of the larger product labour will be able to claim only a share which is smaller in proportion to its contribution; the one goes some way towards counterbalancing the other, and in considering the aggregate reward of labour as a whole, the benefit or detriment of a given event will generally depend on the relative importance of an increased product to a diminished share of that product, or of an increased share of the product to a diminution of the product itself.

$\S 4$. The universal dividend results from the combined acting of a number of units of efficiency. The unit of efficiency results from an effort or abstinence which is not constant but variable. Accordingly a numerical increase in the units of efficiency of one of the agents of production is sometimes accompanied by a diminution, but more often by an enlargement of the effort or abstinence that results in the unit itself.

If the increase of any one of the agents of production results in a more than proportionate 
increase in the universal dividend, it has been necessary to exercise less effort or abstinence in order to bring it about that the unit of efficiency shall come into existence; the law of increasing returns is then said to be operative; for example doubling the labour in a new country often more than doubles its effective power; less labour ${ }^{1}$ then goes to make up a unit of efficiency. But if on the other hand the numerical increase of units results in a less than proportionate increase in the universal dividend more effort or abstinence has been necessary to create a unit of efficiency; the law of diminishing returns is then said to be in operation; to take an instance, doubling the labour expended on an area of land already highly cultivated, does not double its produce; more labour ${ }^{1}$ is now required to make up a unit of efficiency.

How then may we determine what a unit of efficiency is? It may be defined as accruing from that amount of effort or abstinence the product of which is at one given moment a given fractional part of the universal dividend. So long as the

$1 N^{\top}$ ot however necessarily less or more labour in exact proportion to the increased or diminished returns, for the "balance of power" between labour and the other agents of production may be disturbed, and it may consequently result that the more or less of effort or abstinence required to generate a unit of efficieney is affected in the other agents of production likewise. 
universal product remains unchanged the total number of units of efficiency does not alter. But they may result from increasing effort or abstinence on the part of one agent of production, concurrently with decreasing effort or abstinence on the part of another; and in such a case actual numerical increase of those generated by one agent of production would take place coincidently with a numerical decrease elsewhere. Thus next year more men of given strength and skill may work than this, and fewer thousands of pounds may conceivably be industrially employed than now ; the one change may counterbalance the other, and the universal dividend remain unaltered.

But supposing there to be an increase in the universal dividend the number of units of efficiency must proportionately have increased, and consequently there will have been a greater numerical increase in the units of efficiency of some of the agents of production, than there will have been decrease (if any) in others. There may concurrently have been a shrinkage in the amount of effort or abstinence per unit of efficiency in some of the agents of production, an enlargement per unit of efficiency in others.

The number of units of efficiency is proportionate to the universal dividend. 
The enlargement or shrinkage in the amount of effort or abstinence resulting in a unit of efficiency produced by the various agents of production, depends on the play of supply and demand between these agents of production.

If the money existent in the world were in constant proportion to the universal dividend one unit of efficiency would, in a state of perfect competition, always command the same price. ${ }^{1}$

$\S 5$. In the study of economics there are few things of more importance than to bear constantly in mind the relation between the variation in the total product and the variations in the division of the product. One class of economists has been accused of turning its whole attention to the im-

1 It will be observed that I take into account only the universal dividend, or contemporary increase in the world's wealth, - not the accumulation of ages actually in existence. It might indeed be argued that efficiency that added to the wealth of the world a certain definite amount must be considered less when the world's store of wealth is great than when it is small; but as this treatise is concerned with the division of wealth that is being actually produced amongst those who are concerned in its production, there seems no objection to putting out of account the accumulated wealth of the world, nor to considering efficiency proportionate to the actual wealth-production irrespective of the relation of that production to wealth already existent.

This last matter however is not so completely laid on one side as at first sight appears, for capital which is taken into account as one of the agents of production, bears some rough relation to the accumulated wealth of the world. 
portance of increasing the product irrespectively of how it may be divided. Others have been charged with a neglect of concern for the total product, their whole thoughts being engaged in how a distribution may be secured which shall be advantageous to capital, to land, or to labour, as the case may be. But a complete view of economic problems cannot afford to ignore either the solidarity of interests which universally obtains in the increase of the universal dividend, or the antagonism of human interests which as constantly exists as to its division.

$\S 6$. Of the general theory now exposed that of wages is a particular case, and to discover the effect on wages of any given development we must discover

(1) Its effect on the product of industry,

(2) Its effect on the proportion of that product to which wages will be able to establish their claim.

Even then it will be only of aggregate, not of particular wages, that we shall have ascertained the increase or diminution: and if the case to be considered is one of increased or diminished wage-earning power consequent on an increase or diminution of population we shall have to consider

(3) The changed relation borne by the aggregate to the average particular wage. 
$\S 7$. The theory then assumes that wages, entrepreneurs' profits, interest, and rent are all varying proportions of a varying product of industry, and further that taken together they make up the expenses of production-and that the expenses of production of commodities are only one side of a shield of which the price of commodities is the other; consequently that price can be ultimately analysed so as to trace therein the respective rewards granted to the various agents of production.

$\S 8$. The theory runs counter to a portion of economic doctrine much of which has been accepted in the past, and some of which is current. The next three chapters are therefore occupied in its defence as a whole against doctrines which are inconsistent with it.

Chapter II. considers the theory of the "WageFund" and others logically deduced from it.

Chapter III. considers Professor Walker's theory that rent, interest, and profits of the entrepreneur are fixed by economic considerations independently of the products of industry.

Chapter IV. considers the theory that rent does not enter into the expenses of production.

Each of these theories in turn endeavours rigidly to determine the position that can be claimed by one 
or more of the agents of production irrespectively of the claims of the others. I believe on the other hand that all their claims are mutually interdependent, and that any theory which assumes the contrary is fallacious.

$\S 9$. If my contention is successfully maintained in the next three chapters, then in iny fifth chapter I am free to treat wages as one of the varying proportions of a varying product, and under that hypothesis to consider various labour problems. 


\section{CHAPTER II}

The "Wage-Fund" Theory, and the distum-" $A D e$ mand for Commodities is not a Demand for Labour." Detailed examination of examples taken from leading upholders of these theories: -Mill, Faweett, and Cairnes.

$\S 10$. The exposition of the Wage-Fund theory long received as orthodox in this country, and possibly even yet not quite extinct, is set forth by Mill as follows :-

"Wages then depend mainly upon the demand and supply of labour; or as it is often expressed, on the proportion between population and capital. By population is here meant the number only of the labouring class, or rather of those who do work for hire; and by capital only circulating capital, and not even the whole of that, but the part which is expended in the direct purchase of labour. To this however must 
be added all funds which without forming a part of capital, are paid in exchange for labour, such as the wages of soldiers, domestic servants, and all other unproductive labourers.

"There is unfortunately no mode of expressing by one familiar term the aggregate of what may be called the wages fund of a country; and as the wages of productive labour form nearly the whole of that fund it is usual to overlook the smaller and less insportant part and to say that wages depend on population and capital. It will be convenient to employ this expression, remembering however to consider it as elliptical and not as a literal statement of the entire truth."-(Mill's Political Economy, book ii. chap. xi. § 1.) Quoted also by Cairnes (Leading Principles of Political Economy, part ii. chap. i. §5) as the basis of his argument on this question.

According to this theory then wages are determined by a ratio between capital and population, or in other words the total sum paid to labourers as a whole does not depend on the value of the work performed by them, but on the amount of circulating capital in existence, ${ }^{1}$ and the average amount obtained

1 According to Mill the reward of labour does not depend on the 
by each labourer will be in inverse proportion to the total number of labourers.

$\S$ 11. Professor F. A. Walker in his book on the Wages Question, and in his Political Economy, and Professor Sidgwick in his Political Economy perhaps more completely than their predecessors amongst the opponents of the theory demonstrate that it is untenable, because more efficient labour by the very fact of its greater efficiency creates an additional fund out of which it will be recouped; - that in fact "there is no wage-fund irrespective of the number and industrial quality of labourers."

\section{Professor Walker says :-}

"If we assume that upon a cultivated island are tools and carts and animals for draught and other forms of capital adequate for a thousand laborers, the production will vary within a very wide range according to the industrial quality of the laborers using that capital. If we suppose them to be East Indians we shall have a certain annual product; if we suppose Russian peasants to be substituted for

efficiency of the actual work contemporaneously paid for, though no doubt he cousidered it was influenced by the efficiency of labour that had taken place in the past; for efficient labonr would have produced profits, and part of profits would have been used as circulating eapital, and part of this in turn would go to form the "wage-fund." 
East Indians we shall have twice or three times that product; if we suppose Englishmen to be substituted for Russians we shall have the product multiplied two or three fold. An Englishman will do from three to thirty times as much work in a day as a Bengalee according as the nature of the work makes smaller or larger demands upon the skill and strength of the laborer. By the wage-fund theory the rate of wages would remain the same through these changes inasmuch as the aggregate capital of the Island and the number of the laborers in the market would be unchanged, the only difference being found in the substitution of more efficient for less efficient laborers. According to the view here advanced on the contrary, the amount to be paid in wages should and would rise with the increased production due to the higher industrial quality of the laboring population" (because the employers would compete amongst each other for the more efficient labor and would be willing to pay more to secure it). "Whether it would rise in exact proportion thereto is not the question we are now considering."-(F. A. Walker, Political Economy, part vi. chap. vi. § 404.) 
Professor Henry Sidgwick has a most luminous chapter on "General Wages" in his Principles of Political Economy (book ii. chap. viii.), in which he completely overthrows the wage-fund theory.

That hypothesis rests on the assumption that labour whilst engaged upon an undertaking must be supported by capital (i.e. the result of saving from the proceeds of former undertakings) and that this support by capital will constitute the whole of the wage received. Now a certain amount (at least enough to give a mere subsistence) it is true must often be advanced in this way in the first instance, but it by no means follows that the advance represents the whole wage. Professor Walker says :-

"In new countries, by which we mean those to which men have gone with the industrial ideas and ambitions of older communities, but with an amount of capital which from the necessity of the case, is more or less inadequate to the undertakings for which their skill and labor qualify them, the wages of labor are paid only partially out of capital." . . . "From the first settlement of the colonies down to the discovery of gold in California, laborers whether in agriculture or in manufactures were as a rule hired by the year and paid at the end of the 
year. Bare subsistence might be furnished by the employer meanwhile" ... " but these payments were not to such an extent (except in case of protracted sickness or sudden misfortune) but that the employer was always in debt to his laborer." . . . "When the employer shall pay is a financial question ; what he shall pay" ... " is determined by the efficiency of labor under the conditions existing at the time and place." [The Wages Qucstion, part i. chap. viii. "The wages of the laborer are paid out of the product of his industry.']

$\S 12$. The advocates of the wage-fund theory found themselves led to the following result. All people consumc wealth, but some replace it whilst they are doing so, others do not, hence it comes that there is what is called productive, and unproductive, consumption of wealth, the latter alone permanently diminishing the amount of wealth in the world. According to the wage-fund theory the unproductive consumption of wealth meant a diminution of the part of the world's wealth which would be used as circulating capital, that was synonymous with a diminution of the wage-fund, and that meant lower wages for the bread-winners all round. What more natural than that the supporters of this theory should show if they 
could that the expenditure in luxuries did not add anything to the total wages received by the wageearning classes? Hence arose the doctrine on which so many of us were nurtured "A demand for commodities is not a demand for labour."

$\S 13$. This again I believe to be entirely fallacious, and though we may perhaps be permitted to take it for granted that the wage-fund theory has been satisfactorily disproved, a detailed examination of the chapters of Mill, Fawcett, and Cairnes in which the latter dictum is expounded, is I fear necessary, although the latest important authoritative work on Economics, Professor Marshall's Principles of Economics, summarily dismisses it (see conclusion to the note at the end of the 2nd Chapter of Book VI.)

Examination of the proposition " $A$ dcmand for comnodities is not a demand for labour." Mill's "Political E'conomy," book i. chap. v. $\$ 9$.

$\S 14$. Mill supposes that at a given moment there is a certain amount of capital in existence which will set going a certain amount of labour, and apparently that there is a certain amount of purchasing power which, when the manufacturer is warned of the course it is about to take, can influence the direction of 
Iabour, "it determines the direction of the labour; but not the more or less of the labour itself." It is unnecessary to analyse all his examples, but we will examine some of those in which the issues involved are most clearly brought out :-

Thus he says a consumer may employ part of his income " in hiring journeymen bricklayers to build a house, or excavators to dig artificial lakes, or labourers to make plantations and lay out pleasure gardens; or, instead of this, he may expend the same value in buying velvet and lace."

Mill holds that in the first case there is a direct benefit to the working classes, by creating a demand for labour by means of which wages are raised, or the number of labourers in employment increased; but that in the second case there is not. The case at first sight looks a fair one enough, for the man is simply studying his own pleasure in either case, whether he is digging fish-ponds or building a house, or whether on the other hand he is buying velvet. If then Mill can prove that the first course is more advantageous to the working classes than the second, it would seem to go a long way towards establishing his position that a demand for commodities is not a demand for labour. But really to put the cases on 
an equal footing we must suppose that digging fishponds, or let us say bricklaying, for that is the example he follows out, requires as much fixed capital, and also as much of that part of circulating capital which is not spent in wages, as making velvet does ; otherwise the comparison will not be between a direct demand for labour and a demand for commodities, but between an occupation which requires no fixed capital and no raw material, and one in which these are necessary. As the latter is not the problem we are considering, to make the example a fair one, we must suppose that as much money would be spent in mortar-machines and the like as in velvet-making machines, etc., and that it costs as much to buy the bricks from which the house is built as it does to buy the raw material for the velvet manufacturer.

We are now in a position to pursue Mill's argument. He supposes that the consumer who has before spent his money in paying bricklayers "determines to prefer velvet, for which he thus creates an extra demand. This demand cannot be satisfied without an extra supply nor can the supply be produced without an extra capital ; where then is the capital to come from? There is nothing in the consumer's change of purpose which makes 
the capital of the country greater than it otherwise was." This question "Where then is the capital to come from?" is asked us as if it were an enigma. But surely the capital required by the velvet-manufacturer both fixed and circulating is liberated from the bricklaying enterprise. The money that has before gone to buy the mortar-machines and bricks will now furnish forth a new annex to the velvet factory and buy raw material; the wages before paid to the bricklayers will now be paid to the velvet operatives. This indeed Mill proceeds in effect to remark :- " the very circumstance which gave rise to a" demand for velvet, "has set at liberty a capital of the exact amount required." But at this point Mill instead of completing the example in the way we should expect by saying that just as the capital which formerly went to make a house, now goes to make velvet, so the labourers who formerly laid bricks, will now make velvet (for in this example he presupposes perfect mobility of labour), he takes the round-about course of saying that the bricklayers will be thrown out of work altogether, and the workers who formerly made food for them will become velvet-makers. Well be it so. The case for the poor ex-bricklayers is still not so desperate as Mill wonld have us believe; he holds that they will either have to go without food 
and necessaries, or squeeze a competence by their competition from the shares of other labourers. But why not set them to produce food and necessaries for the new velvet-makers (the men who formerly produced food and necessaries for them)? Happy expedient! Mill seems to be in the position of a man who has taken three pegs out of three holes and having replaced two of them in positions they did not formerly occupy, wonders what on earth he shall do with the third. But now a difficulty about the capital crops up again. Mill says "There was capital in existence to do one of two things, to make the velvet or to produce necessaries for the journeymen bricklayers," but " not to do both." Now as to that there have already been two capitals in use, the one employed in the plant of the master-bricklayer's business, in buying the bricks, and in paying his men's wages. The other in similar fashion as fixed and circulating capital in the businesses of the providers of necessaries. These can now respectively be invested in plant, stock, and wages in the velvet manufacturer's business, and (as before) in the businesses of the providers of necessaries.

Never surely was so hardy an attempt made to draw a distinction where no difference exists!

But probably attention may fasten itself on that 
small part of the velvet-maker's capital which will be required by him to buy raw material and support his labourers till the returns from his business begin to come in. Where is it to come from? Surely it will be found in undiminished returns in the bricklayer's business contemporarily with reduced weekly bills for labour. The master-builder will go on letting new houses, and increasing his rent-roll for some time after he has discharged his men.

In the instance our author takes next the circumstances are reversed, and the man who formerly spent his money on velvet, amends his ways, and takes to employing bricklayers. The passage reads thus :"Every one knows that the capital invested in an employment can be withdrawn from it, if sufficient time be allowed. If the velvet-maker had previous notice, by not receiving the usual order, he will have produced $£ 1000$ less velvet, and an equivalent portion of his capital will have been already set free. If he had no previous notice, and the article consequently remains on his hands, the increase of his stock will induce him next year to suspend or diminish his production until the surplus is carried off. When this process is complete, the manufacturer will find himself as rich as 
before, with undiminished power of employing labour in general, though a portion of his capital will now be employed in maintaining some other kind of it."

"Where there was formerly only one capital employed in maintaining weavers to make $£ 1000$ worth of velvet, there is now that same capital employed in making something else, and $£ 1000$ distributed among bricklayers besides. There are now two capitals employed in remunerating two sets of labourers; while before one of these capitals, that of the customer, only served as a wheel in the machinery by which the other capital, that of the manufacturer, carried on its employment of labour from year to year."

[That is to say that these two capitals were previously the one of them circulating and the other fixed, but that is just what is still the case.]

I think we can put the case more tersely than Mill does; the $£ 1000$ formerly spent on velvet went to pay cost of raw material, wages, and profits in the velvet business. After the change it will be spent in the price of houses and do just the 
same in the bricklaying business. The fixed capital released in the velvet manufacturer's business, will also be required by the master-bricklayer.

(Mill seems to take for granted that a fixed capital will be released in the velvet-maker's business, and that none will be required in the builder's.) There remains to be considered the small portion of the velvet-maker's circulating capital that will accumulate during the time he is selling off his old stock, that is to say whilst his wages bill is lessened and his receipts are as yet undiminished. The newly established builder will have to borrow this money to pay his wages, etc., till he gets into full swing and begins to realise returns from his business :-it is for him a necessary initiatory expense.

Mill now summarises lis results and I will quote what he says in one column, and make my criticisms in another parallel to it :-

"The proposition for which I am contending is in reality equivalent to the following, which to some minds will appear a truism, though to others it is a paradox : that a person cloes good to labourers not by what he consumes on himself, but solely by what he does not consume. ${ }^{1}$
1 This proposition is a truism if the abstention from consumption is perpetual.

But it is a paradox if consumption is merely postponed.

The mere postponement of consumption does not make the world richer, except to the extent of the interest 
"If instead of laying out $£ 100$ in wine or silk, I expend it in wages, the demand for commodities is precisely equal in both cases: in the one it is a demand for $£ 100$ worth of wine or silk, in the other, for the same value of bread, beer, labourers' clothing, fuel, and indulgences, ${ }^{2}$ but the labourers of the community have in the latter case $£ 100$ more of the produce of the community distributed among them. $^{3}$ I have consumed

which accumulates in the meantime on the temporarily unconsumed capital. But when consumption eventually takes place the interest is probably consumed also. If Not and a man consumes $£ 100$ at the end instead of at the beginning of a year, he will be in a position to make a present of perhaps $£ 4$ interest to the community if he chooses to do so, but he does not necessarily take this course.

2 This is not fair : in the first instance Mill considers the $£ 100$ circulating capital to be in the first hands which it reaches, in the second instance he takes it to be in the second hands which it reaches. In the first instance, just as much as in the second, the operatives will have to PASs ox the $£ 100$ to buy bread, beer, labourers' clothing, etc. In the second instance, just as much as in the first, the $£ 100$ will be paid in the first place to the labourers. There is really no difference whatever ${ }^{3}$ and it is 
that much less, ${ }^{4}$ and made over my consuming power to them. If it were not so, my having consumed less would not leave more to be consumed by others; which is a manifest contradiction. When less is not produced what one person forbears to consume is necessarily added to the share of those to whom he transfers his power of purchase.

"In the case supposed I do not necessarily consume less 5 ultimately since the labourers whom I pay may build a honse for me, or make something else for my future consumption. But I have at all events postponed my consumption and have turned over part of my share of the present produce of the community to the labourers. ${ }^{6}$ If after an interval $I$ am indemnified it is not from the existing produce, but from a subsequent addition male to it. ${ }^{7}$ I have therefore left more of the existing produce to be consumed by others $i^{8}$ and have put into not true that in the latter case $£ 100$ more of the produce of the community is distributed amongst the labourers.

4 Nor is it true that I have consumed that much less; the labourers are making for my consumption commodities just as genuine as wine or silk.

5 That is to say then that according to Mill a man does in some circumstances do good to labourers by what he (eventually) consumes on himself.

6 If the consumption is postponed it simply means that there is more of it. Instead of paying $£ 1000$ for wine and silk at the beginning of the year, I have at the end of it a house worth $£ 1040$.

7 On the contrary I am indemnified by the produce which formerly existed AND the subsequent addition made to it.

8 I lave not left more of the existing produce to be consumed by others, or if I have done so temporarily I have demanded at the end of 
the period for which the loan has been made a larger share of existing produce. If I consume the larger prothe possession of labourers the power to consume it." 9 duce at the end of the time ${ }^{9} \mathrm{I}$ am not befriending the community any more than if I had consumed the smaller produce at the beginning of it.

Mill is not even yet satisfied that he has made his case clear, and well may he be distrustful about it. He says

"There cannot be a better reductio ad absurdum of the opposite doctrine than that afforded by the Poor Law. If it be equally for the benefit of the labouring classes whether I consume my means in the form of things purchased for my own use, or set aside a portion in the shape of wages or alms for their direct consumption, on what ground can the policy be justified of taking my money from me to support paupers?"

The new element of confusion here introduced is talking about wages and alms as if they were synonymous. 
If the paupers are capable of earning wages then the policy of the Poor Law can not be justified. But if the panpers from whatever cause are not capable of earning wages then they must be given alms. For alms there is no return, and the poor rate will have to be paid at a sacrifice of what might otherwise have been expended in commodities.

Mill now amplifies his argument in a long note in which he supposes that "A expends a portion of his income in wages or alms." There could not be a more complete refutation of his theory than the fact that it necessitates regarding expenditure in wages and in alms as being economically the same, i.e. it makes no difference whatever whether you get a quid pro quo for your money or not! If this were so, philanthropy would become very cheap indeed. I do not think it necessary to follow the long course of this note as it contains no new argument. If you take it that A gives alms, all that it says is true; if on the other hand you take it that $\mathbf{A}$ gives wages, the same fallacies appear as before; $\mathrm{B}$ his successor spends his money in luxuries, these "luxuries must be produced not instead of, but in addition to the food previously supplied to A's labourers "-this is of course true, but so must formerly the quid pro quo 
whatever it was that $A$ received in exchange for the wages he paid.

We can sympathise with Mill when he remarks with a sigh at the outset of his consideration of this thorny theory, "A demand for commodities is not a demand for labour" - "It is no wonder that political economy advances slowly, when such a question as this remains open at its very threshold."

\section{Fawcett's "Manual of Political Economy," Fifth Edition, book ii. chap. iv.}

$\S 15$. Fawcett too declares that "the proposition that a demand for commodities is not a demand for labour, is a proposition which is perhaps more rarely understood than any other in the whole range of political economy."

We need not examine all his examples. We find the same failure to define whether fixed or circulating capital is being spoken of, and the same consequent confusion. We find too the same assumption that money distributed amongst the labourers as wages is the same sort of benefit to them as if it were distributed as alms without any quid pro quo. The idea is one that would naturally shape itself in the mind of economists who held the wage-fund theory, for 
anything that added to that fund would be of the nature of a free gift to the labouring classes. But this need not weigh with us now that it has been so clearly proved by Walker, Sidgwick and others that the wage-fund theory is fallacious.

Some of Fawcett's illustrations are however curious; take for instance the following, which he ushers in with the remark "The truth of the proposition shall be tested by the most extreme case which even an opponent can suggest."

He says that if his proposition is true the purchase of $£ 50$ worth of some useless luxury like lace does no more good to the community than if the individual wantonly destroyed $£ 50$ worth of property. Well this is of course true (if one can fairly put out of account for the moment the satisfaction of the buyer of the lace who is after all one of the community), but it does not in any way prove that the demand for lace is not a demand for labour. If the lace manufacturer is to replenish his stock he will have to employ labour to do it, and similarly labour would have had to be employed to make good the wanton damage done to property. It is true that both cases are on the same footing, but they are both on a quite different footing to that which he seeks to prove they stand on. He holds that neither circumstance 
causes a demand for labour; the fact is that both of them do.

We may here give in parallel columns Fawcett's three conclusions and the corresponding conclusions to which we have been led-

1. A man may spend money on luxuries $;^{1}$ then wealth is consumed in simply giving him pleasure.

2. A man may spend capital on labour that is not reproductive of wealth ;

2 then capital is consumed in simply giving food to labourers.

3. A man may spend capital on reproductive labour;

3 then capital is not only reproduced but also gives the same amount of support to the labourers as in the second case
1 Then wealth is consumed in giving him pleasure and (through the intermediary of another person) he gives employment to labour with the object of producing wealth of this kind, and this enables the labourers to procure food.

2 Then wealth is consumed in giving him pleasure and (without the intermediary of another person) he gives employment to labour with the object of producing wealth of this kind, and this enables the labourers to procure food.

[Note that there is no such distinction as is sought to be established by Fawcett between the first and second case.]

3 Then the total of existing wealth is not diminished as in cases Nos. 1 and 2 , but the advantage of there being a greater amount 
of wealth in existence does not accrue to the community as a whole, but to the man who has not so far consumed it in giving himself pleasure. What he will do with itwhether he will devote it to the good of the community or not, remains an open question. He gives direct employment to labour exactly as in the second case and with the same results.

Fawcett's Manual, Sixth and Seventh Editions(the same chapter).

$\S 16$. The chapter which treats of this subject has been considerably modified in the sixth and seventh editions of Fawcett's Manual. It has been shorn of many of the most striking passages on which comment is made above. But though more circum. spect in expression, and though it even suggests that Mill's view that $£ 1000$ spent in velvet is much less beneficial to the labourers than if it were spent in making an artificial lake "requires considerable modification," there is a want of clearness and grasp in the treatment of the subject perhaps even more marked than in the earlier editions, and the argu- 
ments are throughout vitiated by an undercurrent of belief in the wage-fund theory.

The contention is that "unproductive consumption of commodities diminishes the amount which may subsequently be devoted to paying the wages of labour" (Seventh Edition, p. 22). Now if by this were meant that industry which is bencfited by the existence of capital will be benefited less by the existence of less capital, and that consequently a diminution of capital diminishes labour's share of the total product, the truth of the proposition might be admitted at once. This simply means that destruction of capital tends to raise the rate of interest which in turn handicaps industry. But this by no means measures what is intended to be understood, which is nothing less than that the wage-earners suffer to the extent that there is unproductive consumption. Now the amount of injury inflicted on the wage-earner by the withdrawal of capital for purposes of unproductive consumption in a well-established industrial organisation is usually infinitesimal ; on the other hand in a new country where capital is scarce in comparison with the other agents of production the consequences may be serious, but even under the circumstances where the consequences would be worst the resultant disadvantage to industry, or at all events to that part 
of the total product of industry accruing to labour, could hardly ever amount to as much as the actual amount withdrawn.

The view set forth by, Fawcett then both exaggerates the effect on industry of the withdrawal of capital, and neglects to take into account the great difference that there will be in such effect in varying circumstances. In a state of industry ill supplied with eapital in proportion to the other agents of production-(land, entrepreneur power, labour)-it may be serious; but in a state of industry superabundantly supplied with capital in proportion to the other agents of production it will be trivial.

The withdrawal from investment for unproductive consuinption of a million of money if it took place in New Zealand would more sensibly affect the wageearner's position than it would in England, but in neither case would it affect it to the extent of

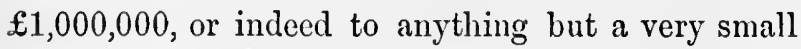
fraction indeed of that amount.

Cairnes's "Leading Principles of Political Economy," part ii. chap. $i . \S 7$.

$\S 17$. Cairnes attempts to reduce the theory that a demand for commodities is a demand for labour to 
an absurdity, by comparing the actual statistics relative to England and the United States $;^{1}$ he concludes that the gross produce per head of the population in the two countries is approximately the same, therefore that the demand for commodities is in both countries about the same in proportion to population; and that according to the theory which he is controverting the quantity of wealth spent in the wages of labour is therefore about the same per head. ${ }^{2}$ How then comes it about that wages are so much higher in America than in England? This certainly disproves the assertion that all that is spent in commodities is spent in recompensing labour but it does not as Cairnes asserts bring us to Mill's conclusion

${ }^{1}$ Cairnes begins his task by controverting Longe's proposition that demand for commodities determines the quantity of wealth spent in the wages of labourers. But (it would seem almost unconscionsly to himself) he slips into enlarging the scope of his contentiou, and goes on to argue that a demand for commodities does not affect the demand for labour. The latter is a much less modest task.

That a demand for commodities is not a demand for labour oNLY may be granted at once, but it by no means follows from this that it is not a demand for labour at all. A demand for one commodity may be a demand for a great deal of labour and a little capital ; a demand for another commodity may be a demand for a great deal of capital and a little labour; but it is always true that a demand for commodities is a demand for some labour.

${ }^{2}$ Here again we must note the enormous assumption which Cairnes gratuitously couples with the belief that demand for commodities affects demand for labour. He assumes that it is asserted that the quantity of wealth spent in wages is directly proportionate to the demand for commoditics. 
that the demand for commodities does not determine the more or less of what the labourer on an average receives. From the price of commodities we have to make deductions of rent, and of interest on fixed capital, and entrepreneurs' profits, (besides taking taxation into account and this may not be uniform in the two countries), and it is only what is left after making these deductions that goes to recompense labour. Now rents are higher in England than in America, ${ }^{1}$ but it will be urged that on the other hand, interest is higher in America than in England. Yes, but though interest is higher, much less of it has in the aggregate to be paid because the fixed capital in proportion to labour is very much smaller in a country which is largely agricultural than in a manufacturing country like our own.

Cairnes himself by implication in the section we are considering, and still more clearly a little later in lis book ( $(9)$, lays stress on this point :-

"It is obvious at a glance that a given amount of capital invested in the Western States of North America supports a larger laboring population than the same amount invested in

1 Though of course it does not follow from this that less aggregate rent is on the average paid per individual in America than in England. 
the New England States; and the reason is plain : the former states are more extensively agricultural than the latter and consequently employ fixed capital and raw material less extensively in their staple industries." . . . "Again a comparison of an average investment in the United States-it matters not in what part of them-and in Great Britain would reveal analogous differences."

Most frequently a demand for commodities is a demand in some measure for fixed capital, and sometimes for land, but it is always a demand for labour. The commodities demanded in Great Britain necessitate the employment of fixed capital, land, and labour in different proportions to those demanded in the United States, and this explains how it is possible that an equal demand for commodities in each country may result in labour's receiving a larger recompense in one than in the other; but it remains true that in each country a demand for commodities is a demand for labour.

Let $A$ equal a ccrtain amount of rent, interest on fixed capital, and entrepreneurs' profits, and B equal a larger amount of rent, interest on fixed capital, and entrepreneurs' profits.

Let $x$ represent the demand for commodities. 
The demand for labour in the United States is $x-A$. The demand for labour in England is $x-B$. $x,-\mathrm{A}$ is greater than $x-\mathrm{B}$.

But if $x$ be increased, both $x-\mathrm{A}$ and $x-\mathrm{B}$ will be increased.

$\S 18$. An historical illustration adopted by Cairnes requires notice, though it is aimed not so much at showing that a demand for commodities is not a demand for labour as to support the parent stem from which that dictum springs-viz. the wage-fund theory itself. He says that in Ireland "it became necessary to pass from a crude régime of tillage to one in which capital was extensively converted into fixed and permanent forms." This he regards as a conversion of circulating into fixed capital which resulted in a sudden contraction of the wage-fund "of which the unequivocal evidence is found in a population reduced in a few years from eight to five and a half millions."

But another way of regarding the phenomenon equally consistent with the facts is that capital formerly fixed, now became fixed in another form, where it gave scope for the employment of fewer labourers; that is to say that in the new organisation of industry a larger amount of fixed capital per head was required by the population, there was not enough to "go all 
round," so a large proportion of the population had to emigrate (the matter is considered more in detail in $§ 54$ ). Suppose a farmer has a stock of fifty scythes for cutting his hay. These he sells, and buys a mowing-machine instead. "Four men can now do the work formerly done by fifty, and forty-six are thrown out of employment, but there has been no conversion of circulating into fixed capital. There has only been a conversion of fixed capital from one form to another. 


\section{CHAP'TER III}

Professor F. A. Walker supports the theory that Labour is the residual claimant to the product of industry.

Professor F. A. Walker's "Political Economy," part iv. chap. v. $\S \S 293-297$.

$\S 19$. Professor Walker's book on the Wages Question and the parts of his Political Economy which treat of the same subject are most luminous and may be considered to have finally disposed of the wagefund theory, but I do not discover that he follows up his overthrow of that fallacy by what should follow as a corollary from it, viz. the affirmation of the theory that a demand for commodities is a demand for labour. This I have endeavoured to do in the above pages.

But Professor Walker's own theory of wages lucid as it is, does not I conceive rest on a perfectly sound foundation. He believes that there are for the pro- 
ducts of industry four main destinations, viz. rent, interest, the profits of the entrepreneur, and wages. Of these four he believes the first three are fixed by economic considerations independent of the products of industry and that labour is thus left as "the residual claimant to the product of industry." He says :-

"First, rent is to be deducted. On the lowest grade of lands there is no rent. On the more productive soils rent, at its economical maximum, equals the excess of produce after the cost of cultivating the no-rent soils has been paid. This rent, as we have seen, does not affect the price of agricultural produce, and does not come out of the remuneration of the agricultural labourer. . . .

"We thus see that the first deduction to be made from the product of industry is of a perfectly definite nature, and that, on the assumption of active competition on both sides, the amount of that deduction is susceptible of arithmetical computation. Rent must come ont before the question of wages is considered. . . .

"Secondly, from the product of industry must be deducted a remuneration for the use 
of capital. That remuneration must be high enough to induce those who have produced wealth to save it and store it up, in the place of consuming it immediately for the gratification of personal appetites or tastes. This may imply, in one state of society, an annual rate of interest of eight per cent; in another of five; in another of three. The only reason, industrially speaking, for interest being paid at all is that by the use of capital production may be enhanced; and the interest so paid is only a part often-such is the force of competition among the would-be lenders of capital -only a very small part, of the excess of product so generated.

"Since the product remaining after the payment of interest is always, in theory, equal to what would have been the product, had interest not been paid (that is, had the capital for the use of which interest is paid, not been employed), and since in fact, the product so remaining is always greater, in general, vastly greater, often inconceivably greater, than the product would otherwise have been, that party to the distribution of wealth whose claims are residual, that is, which takes all that no other 
claimant carries away, is benefited by every payment of interest on account of capital used in the production of wealth. ...

"The third and last deduction to be made from the product of industry before the laborer becomes entitled thereto, is what we have called profits, the remuneration of the entrepreneur, the man of business, the captain of industry, the merchant, manufacturer, or banker, who sets in motion the complicated machinery of modern production." . . . The entrepreneur's profits "are of the same nature as rent. As there are no-rent lands, so there is a class of employers who derive from the business they conduct a bare subsistence, at the cost of much anxiety, and perhaps also of discredit, many of them living mainly at the expense of their creditors. "These we call the no-profit employers. From this point, when profits, if any, are so small and so hardly earned that they may, for scientific purposes, be disregarded, upwards through many grades, we have employers who derive moderate profits, liberal profits, grand profits, monumental profits aggregating in a life-time colossal fortunes, according to the degrees in whicl they bring courage, prudence, 
foresight, frugality, and authority over men, to the organisation and conduct of business enterprise. If I am right and not wrong in this view of the nature of the entrepreneur's function and of the source of his profit, those profits would, under full and free competition, not form a part of the price of commodities (price being determined by the cost of production under the most disadvantageous conditions, i.e. in this case production by the no-profits employers); while no economical means whatever would suffice to carry any portion of profits to wages, even were employers forbidden by law to receive profits. In other words, their profits consist wholly of wealth created by the individual employers themselves, over and above the wealth which would have been produced, in similar industrial enterprises, by the same labor-force and capital-force under the control of employers of a lower grade of economical efficiency.

"These three shares being cut off the product of industry, the whole remaining body of wealth daily or annually created, is the property of the laboring class; their wages, or remuneration of their services. So far as, 
by their energy in work, their economy in the use of materials, or their care in dealing with finished product, the value of that product is increased, that increase goes to them by purely natural laws, provided only competition be full and free. Every invention in mechanics, every discovery in the chemical art, no matter by whom made, inures directly and immediately to their benefit, except so far as a limited monopoly may be created by law, for the encouragement of invention and discovery.

"Unless by their own neglect of their own interests, or through inequitable laws, or social customs having the force of law, no other party can enter to make any claim on the product of industry, nor can any one of the three parties already indicated, carry away anything in excess of its normal share, as hereinbefore defined."

$\S 20$. If from the four divisions of the product of industry we deduct three, the fourth is in a sense residual, but I fail to see that Professor Walker shows labour to be the part which receives the residual share by any argument which would not apply with equal justice to any of the other agents of production. Might we not for example argue that labour's share 
was also fixed by economic considerations independent of the product of industry?

'From the point where the wages of labour, if any, are so small, aud so hardly earned that they may for scientific purposes be disregarded, upwards through many grades, we have labourers who receive moderate wages, liberal wages, grand wages, according to the degrees in which they bring strength, skill, endurance, industry, intelligence, trustworthiness, ete., into their work. These wages would under full and free competition not form a part of the price of commodities (price being determined by the cost of production under the most disadvantageous conditions, i.e. in this case production by the labourers who receive lowest wages). The additional wages obtained by the superior workmen consist wholly of wealth created by the individual labourers themselves over and above the wealth which would have been produced, in similar industrial enterprises, by the same entrepreneur-force and capital-force applied to labourers of a lower grade of economical efficiency.'

This argument is of course quite untenable, but is it not a reductio ad absurdum of Professor Walker's? 
Professor Walker argues that the advantage of any improvement in the material conditions of production is lost to the entrepreneur class by their inter-competition for land, capital, and labour, to take advantage of it,- - but it may be urged with just as much truth that it will be lost to the labouring classes by the competition amongst each other to annex themselves to the land, capital, and organising power, requisite for their employment, and we might accordingly then point to one of the other agents of production as receiving the residual portion of the product.

$\S 21$. But the fact is that to regard any one of the claimants to the product of industry as residual is improper; such a view assumes that if changes take place in economic conditions the shares which fall to the other claimants to the product of industry remain constant. This is not the case; a change of economic conditions may and in fact usually does affect rent, interest, and entrepreneurs' profits, as well as wages. 


\section{CHAP'TER IV}

A Criticism of the Economie Doetrine that "Rent does not enter into the Expenses of Production."

$\S 22$. Professor Alfred Marshall in his speech at the meeting which inaugurated the British Economic Association urged that those who were to control its journal should "insist that all who wrote in criticism of others should take the writings of those others in the best possible sense." The chivalrous feeling towards the work of others which prompted this advice animates the first volume of the great work which the Cambridge professor has recently added to English economic writings. The broad tolerance and appreciation of other thought and research in economics which we find in it give its pages a great charm, but this charm has nevertheless, we sometimes feel, the "defect of its quality." Doctrines which have been authoritatively propounded and impressed on the minds of at least one generation. 
of economic students are referred to but slightly and (as it were) by the way, when the author has found them inconsistent with his own more matured theory; indirectly indeed one discerns that they are discountenanced by him, but the discovery that our last master of the science is not on important points at one with some of his great predecessors of a couple of decades ago, is rather concealed than emphasised by himself.

The effect on the mind of the reader is sometimes puzzling: he takes what has hitherto very generally been regarded as the authoritative doctrine somewhat for granted in a writer who does not expressly or at any rate conspicuously disclaim it, and he is consequently disconcerted when he meets with propositions and theories inconsistent with it.

Professor Marshall would probably himself acknowledge that his opinions on the subject (amongst others) of the wage-fund theory, and the theory that "a demand for commodities is not a demand for labour," are essentially different from those that were held by the best English economists in the middle of the century; surely it would have been well if these differences had been a little more decisively indicated.

The treatment of the dictum at the head of this chapter is perhaps an instance of the best interpreta- 
tions being adopted in Principles of Economics without making other than casual reference to another interpretation which may be widespread, and therefore if inaccurate, may be in need of explicit controversion. When Professor Marshall says that rent does not enter into the expenses of production, he means that rent does not do anything towards determining those expenses. But the phrase is ambiguous, and may be construed to mean that rent does not form part of the expenses of production. Some economists indeed have not had the distinction between these two meanings present in their minds and have treated arguments aimed at proving the one, as applicable to the other, and though it is possible that many economists would now disclaim the idea that rent does not form part of the expenses of production, I should be falling into the same error of judgment which I seem to discern in Professor Marshall's writings, were I to ignore their possible interpretation of the dictum which we have before us for consideration, and pass on at once to the examination of that more interesting and more intricate inquiry as to whether it is true to say that rent does not do anything towards determining the expenses of production.

$\S 23$. The Ricardian theory of rent may be illustrated by a diagram. Distance measured horizon- 
tally. From $A_{1}$ to $B$ indicates acreage, thus $A_{1}$ to $A_{2}$ represents 100 acres, $A_{1}$ to $A_{3}, 200$ acres, $A_{1}$

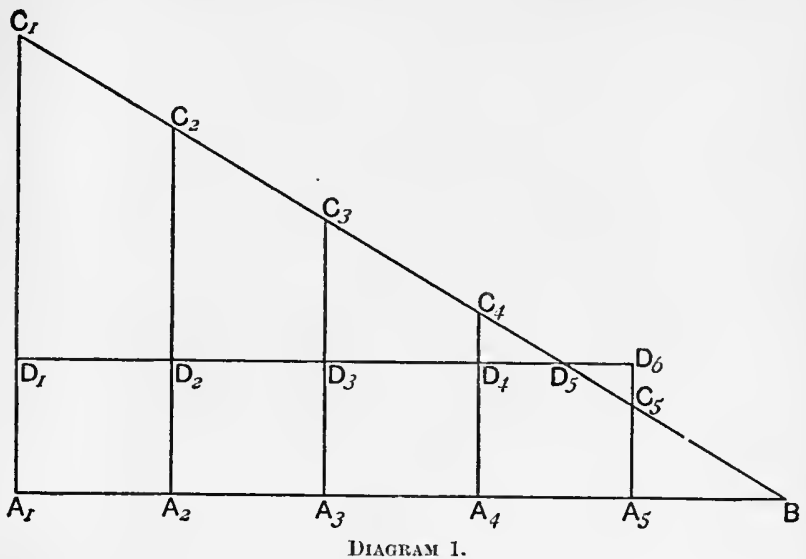

to $\mathrm{B}, 500$ acres. The land is arranged according to capacity for valuable product, and this is measured by the perpendicular lines. Thus with an expenditure of a like amount of capital and labour the first hundred acres will give a product represented by $A_{1} \quad C_{1} C_{2} A_{2}$, the second will give one represented by $A_{2} C_{2} C_{3} A_{3}$, and the fifth hundred acres will give one represented by the triangle $A_{5} C_{5} B$.

Now if we suppose that the farmer's average expenses and profits on a hundred acres of land are represented by the area enclosed between the lines $A_{1} \quad A_{2} A_{3}$, etc., and $D_{1} D_{2} D_{3}$, etc., we shall see that the landlord's surplus of rent on the first hundred 
acres is represented by the area $\mathrm{D}_{1} \mathrm{C}_{1} \mathrm{C}_{2} \mathrm{D}_{2}$, on the second by $\mathrm{D}_{2} \quad \mathrm{C}_{2} \quad \mathrm{C}_{3} \quad \mathrm{D}_{3}$, on the fourth by the triangle $\quad \mathrm{D}_{4} \quad \mathrm{C}_{4} \quad \mathrm{D}_{5}$, less the triangle $\mathrm{D}_{5} \quad \mathrm{D}_{6} \quad \mathrm{C}_{5}$ (that is to say by almost nothing; this hundred acres is said to be about on the "margin of cultivation"), and the fifth hundred acres not only does not pay rent, but it does not even produce enough to recoup the farmer, and will therefore not be cultivated.

Now the first argument that we have to examine is that a bushel of wheat raised on the margin of cultivation is raised where no rent is paid, therefore rent cannot enter into its expenses of production; and as all bushels of wheat of like quality and under like conditions are of the same price whether raised on the margin of cultivation or on rich and accessible soil such as $A_{1} A_{2}$, rent can in no case enter into the expenses of production.

$\S 24$. But in reality nothing could be more inconsequent than this argument. The first part of the Ricardian theory of rent lays down that land of more value than the least valuable land cultivated, pays rent to the extent of that additional value. The argument up to this point is sound; it concerns acres and is applied to acres, and not, as is the case with the second part of the contention, to bushels. However safely we may cross this which Mill calls 
the pons asinorum of economics it by no means follows that if we are invited to trust ourselves to another structure built on much less sound engineering principles we shall not do wisely to tarry on the hither side; and the argument that we are in some quarters asked to endorse (viz. that because surplus value of land whatever it may be, must be paid away in rent, that therefore rent does not form part of the expenses of production) is in fact thoroughly unsound in construction.

It would be as reasonable to argue that if wheat were raised from one farm on which $£ 100$ had been expended in manure, and was sold at the same price as produce raised from another farm on which nothing had been expended in this form of capital, because capital spent in manure did not enter into the expenses of production of wheat from the latter farm, therefore it did not enter into those of wheat grown on the former. Or again we might argue that if wheat grown by Coolie labour sold at the same rate as wheat raised by European labour the surplus of the cost of European labour over Coolie labour could not therefore enter into the expenses of production. What indeed could? Under a process of argument of this kind the expenses of production would "softly and silently vanish away." 
The error will be found to lie in the inconsequence with which an argument founded on acreage is without apology applied to bushels. Now by hypothesis though the price per bushel is uniform the number of bushels raised per acre is various, because the productivity of the land varies, and so what is true of acres will not necessarily be true of bushels.

The acre is in fact a unit from which we can learn nothing at all about land fertility any more than we could about the productivity of labour if we took a man as a unit irrespective of whether he were a Coolie or an Englishman; or any more than we could about the productivity of capital if we took a coin as a unit, irrespective of whether it were copper or gold.

$\S 25$. Let us reconstruct our figure but let distance measured horizontally along the line $A_{1} A_{2}$, etc., represent instead of hundreds of acres, units of efficiency in land, thus $A_{1}$ to $A_{2}$ measures one unit of efficiency, $A_{1}$ to $A_{3}$, two units, and so forth.

The produce will always be the same, a fixed proportion of it goes to rent, a fixed proportion of it to reward capital, labour, etc., whatever the acreage; whether it be a square yard in the heart of the City of London or a square mile on a Scotch 
sheep-run, with a like expenditure of capital and labour the occupier can afford to pay a like rent.

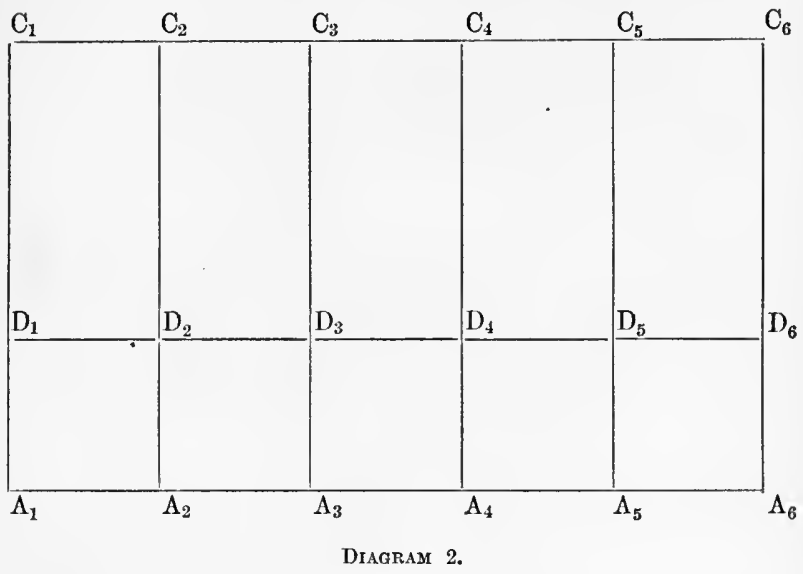

$\S 26$. Now we will let our line $A_{1} A_{2}$ etc., instead of representing units of land with like efficiency for produce, equal expenditure of capital and labour being made thereon, represent units of land giving equal products, but with unequal application of capital and labour. Distance measured horizontally now marks units of land acreage, each of which produces say 1000 bushels of wheat. Thus on $A_{1}$ $A_{2}$ will be grown 1000 bushels of wheat, on $A_{2} A_{3}$ 1000 bushels, and so forth. The land is ranged as in the first figure according to natural capacity for valuable product, that from $A_{1}$ to $A_{2}$ being the most, 
and that from $A_{5}$ to $A_{6}$ being the least, fertile, accessible, and so forth.

Of the produce raised on $A_{1} A_{2},-A_{1} C_{1} C_{2} A_{2}$ goes to pay rent; $C_{1} D_{2} C_{2}$ goes to reward capital and labour. Of the produce on $A_{5} A_{6},-A_{5} C_{5} A_{6}$ pays rent, $C_{5} D_{5} D_{6} A_{6}$, pays for capital and labour.

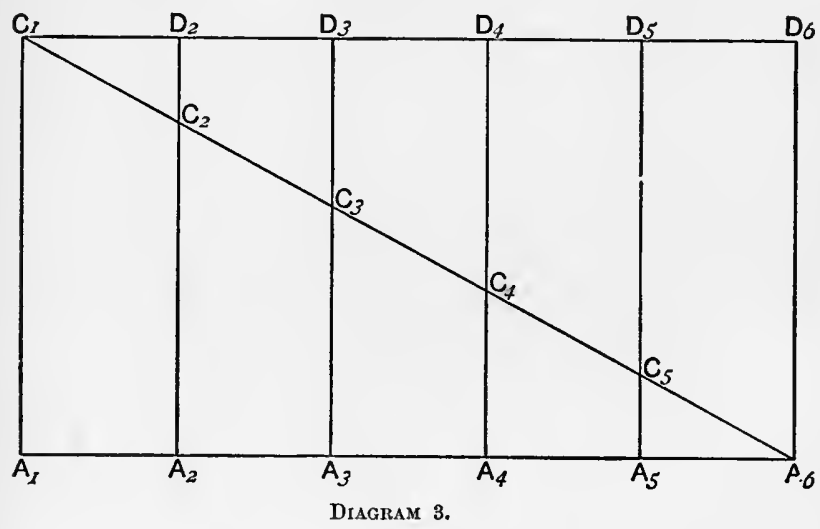

Of the prices paid for the respective thousand bushels of wheat, sometimes more, sometimes less, goes to pay rent, but the more that goes to pay rent, the less goes to pay for capital and labour, and vice versa, and surely we cannot say that one more or less than the other forms part of the expenses of production. Rent forms part of the expenses of production of wheat which is grown on land that pays rent, it does not form part of the expenses of production of 
wheat raised on land that pays no rent, but in the latter case the expenses of production on account of capital and labour are larger proportionately, and this accounts for the fact that the total expenses of production in the two cases are identical.

$\S 27$. But though the above considerations seem to show that the doctrine that rent does not form part of the expenses of production may be denied with a considerable degree of confidence, we have still before us by far the most important part of our investigation.

We now have to consider whether it is true to say that rent does nothing to determine the expenses of production.

A distinction may be drawn in Diagram 3 between the triangle $A_{1} C_{1} A_{6}$, which represents rent, and the triangle $C_{1} D_{6} A_{6}$, which represents the reward of capital and labour, on the following grounds. The supply of units of efficiency of capital and labour tend to adjust themselves to the demand, but it is maintained that it is impossible that the units of efficiency of land should do so, because of land there is a certain definite limited quantity. Professor Marshall says (Principles of Economics, book vi. chap. i. $§ \$ 4,5)$ :"The amount of the commodity and its price, the amounts of the several factors or agents of production used in making it, and their prices, 
-all these elements mutually determine one another, and if an external cause should alter any one of them the effect of the disturbance extends to all the others. . . . Here however we must call to mind a fundamental difference between earnings and interest on the one hand, and rent on the other. For rent is not one of those mutually determining elements, but is determined by them. The rent or Producer's Surplus of a differential advantage, not made by man, is the excess value of the return which can be got.by its aid where labour and capital are applied with normal ability up to the margin of profitableness, over that which the same labour, capital, and ability, would get if working without the aid of any such advantage."

The doctrine is expressed in another form (book v. chap. viii. end of $\S 4$ ) :-

"The price of agricultural produce taken as a whole is governed, in the long run, and other things being equal, by its marginal expenses of production (or, to use the ordinary metaphor, by the expenses on the margin of cultivation); ... these expenses are not in any way affected, directly or indirectly, by the true rent (exclusive of the quasi-rents for improvements) paid for 
the land ; and ... therefore this rent does not enter into the expenses of production of agricultural produce taken as a whole."

$\S 28$. It is again expressed thus by Professor W. R. Sorley of the South Wales University College, in his monograph on Mining Royalties (Hy. Frowde, Oxford University Press Warehouse) p. 16 :-

"The theory of agricultural rent is perfectly precise"... "according to it rent does not enter into the price of the product; it is the price of the product that determines rent. In the perfect market there will be only one price for commodities of the same quality, and that price will be fixed by the expenses of the production of the commodity under the most unfavourable conditions-by that portion of the article which is produced with greatest difficulty or from the least fertile and advantageously situated land. Such least fertile land will pay no rent or a minimum rent that may be disregarded. But the expenses of the production there, will fix the price of the product, and the more fertile or better situated land will pay a rent corresponding to its greater advantages. Were rents to be abolished to-morrow by a stroke of the pen the abolition would but enrich 
the tenants of the more fertile soils. The same amount of corn and cattle would be required as before; the conditions of production would be the same in the least advantageous circumstances. These would fix the price of the product; food would not be cheaper and wages would not be raised."

"Were rents to be abolistical to-morrow,"-but in the supposed case given by Professor Sorley rents are not abolished. So far as the consumer is concerned, so far as the wage-earner is concerned, landlords have not been abolished at all; there is simply a new set of them. The quota of rent is paid out of the consumer's payment for commodities as certainly now to those who were formerly the tenants as it was before to the landlords. It is therefore no matter for surprise that food is no cheaper and wages not raised. The only people for whom rent is really abolished by this stroke of the pen are the quondam tenants, and for them the expense of the produce of their farms is diminished by exactly that amount, showing that rent did enter into their expenses of production. Similarly if a law were passed that all loans now contracted should be binding, but that the agreement as to interest payable thereon, should not be binding, this might be called doing away with 
interest by a stroke of the pen. It would not cheapen food, it would not raise wages; it would but enrich the borrowers. The more they had borrowed the more they would be enriched. Yet no one would adduce this as an argument to prove that interest does not enter into the expenses of production.

Professor Sorley's argument is an excellent one if aimed to show the impossibility of abolishing the payment of rents by consumers, but it does not show that rent does not enter into the price of the product.

Here it may be noted that whereas Professor Sorley's contention began with laying down that rent is determined by the price of the product, the argument he has chosen as illustrative of his position is directed in reality not to this point at all, but to the different question as to whether rent forms part of the price of the product. This seems to justify my contention that the two questions have not been kept distinct in the minds of economists; at the same time it follows that even though Professor Sorley's illustration may be logically defective, his original contention that rent is determined by the price of the product may be correct.

$\S 29$. Now unquestionably there is a connection between rises and falls in general prices and rises and falls in rents. The received economic doctrine is that rents are determined by, but never determine, 
prices. Whilst fully admitting that changes in prices probably would affect rents, I propose to put forward the unorthodox contention that it is also possible that a change in rents may precede and be the cause of a general change in prices; that in fact rent and prices are "mutually determining elements."

$\S 30$. Now on what does the contrary contention rest? Undoubtedly it rests on the hypothesis that land is limited and that its inherent properties are “incapable of increase by man's effort in any period of time however long." 1 Were this the case both those who had land to let and those who wished to rent it would be under the sway of the law of supply and demand, but if the public desire for land increased it would mean that there would be no means of satisfying that increased desire and the only way of equalising supply and demand would be by raising rent. If we were considering not land, but Raphael's Madomnas, this would be true; but in the case of land I hold that it is very far from being true. Even the actual area of land is susceptible of increase to meet an increased demand (land can be reclaimed from sea or bog as in Holland or Ireland) but the

1 This is an expression used by Professor Marshall in the first edition of Principles of Economics (book vi. ehap. iii. § 1) in a passage which has been eliminated from the second edition of the book. 
actual area of land is of very little moment. What we have to consider are those qualities in land for which we are willing to pay. These qualities may be roughly classed under the two heads of (1) fertility and (2) accessibility. Palpably, both these classes of desiderata can be increased by man's effort; tillage, draining, manuring, etc., will increase the first; making new roads, new railways, new steamboats, will increase the second.

"Other things being equal, the larger the supply of any agent of production, . . . the lower will be the demand price with which it will have to be contented. . . . The extra production resulting from the increase in that agent of production will go to swell the National Dividend, and other agents of production will benefit thereby, but that agent itself will have to submit to a lower rate of pay" (Marshall, bk. vi.ch.ii. § 2). By the improvement of communication, land is for all practical purposes rendered more plentiful, and it is in consequence of this that rents fall. Rents once having fallen, it follows that commodities can be produced more cheaply, because a smaller proportion of their price has to be allocated to the payment of rent. Improved communication affects the supply of one of the agents of production; that 
is a sufficient explanation of a change in its remuneration. The cause of a fall in rents is thus identified and we must see in the fall of the prices of commodities, not another cause, but an effect of the fall in rents.

$\S 31$. A passage from Mill, though of course the instance is given by him in another connection, illustrates my meaning. He says:-

"The roads, railways, and canals" (of Great Britain) "were not constructed to give value to land; on the contrary, their natural effect was to lower its value, by rendering other and rival lands accessible:-and the landlords of the southern counties actually petitioned Parliament against the turnpike roads on this very account. The tendency of improved communication is to lower existing rents, by trenching on the monopoly of the land nearest to the places where large numbers of consumers are assembled. Roads and canals are not intended to raise the value of the land which already supplies the markets, but (among other purposes) to cheapen the supply by letting in the produce of other and more distant lands; and the more effectually this purpose is attained, the lower rent will be. If we could imagine that the railways and canals of the United 
States, instead of only cheapening communication, did their business so effectually as to annihilate cost of carriage altogether, and enable the produce of Michigan to reach the market of New York as quickly and as cheaply as the produce of Long Island, the whole value of all the land of the United States (except such as lies convenient for building) would be annihilated ; or rather the best would only sell for the expense of clearing and the Government tax of a dollar and a quarter per acre; since land in Michigan equal to the best in the United States may be had in unlimited abundance by that amount of outlay" (Principles of Political Economy, book ii. chap. xvi. § 5).

The decrease in the value of agricultural land in this country since the inproved communication with America, which (no longer counterbalanced by corn laws) is equivalent to an enormous increase in our own available agricultural land, is another instance in point. Converse instances are more difficult to find in actual experience. It is easy enough however to imagine one. Supposing an eccentric duke were suddenly to devastate half London and enclose it as a deer park, industrial enterprise would be compelled to seek less advan- 
tageously situated land, the industrial product of the country would be diminished and prices would rise.

$\S 32$. Practically then we can create, or we can destroy, land, or those qualities of land for which rent is paid. And if land can thus be created it is to all intents and purposes a form of capital, and it is surely unreasonable to maintain that the interest on capital expended in making bread does, whilst the interest on capital expended on "making" the land on which corn is grown, does not, enter into the expenses of the product,-bread. "Natural advantages" and artificial advantages sell in the same market, and are in fact indistinguishable from each other, and since the latter can be increased by man's effort, we cannot regard the former as being in the same position as Raphael's Madonnas, for though other pictures may be produced which may more or less enter into competition with them, it is impossible that any shall be produced which shall be indistinguishable from them and identical with them as a commodity in the market.

$\S 33$. It is quite true that the land, and that the capital irretrievably sunk thereon, is completely immobile and that it is therefore in a position of absolute powerlessness as to determining prices. But though this is true of particular cases in which 
rent is paid, it is not true of the payment of rents as a whole.

It is of course well recognised that (whether we have under consideration an agent of production, or a commodity) it is not needful for mobility to pervade the whole of that agent of production, or that commodity, for it to continue in the sphere of influence of mutually determining values. Thus if Raphael were still living, and in possession of his powers, although those of his Madonnas which are already in existence would be as economically immobile commodities as they are at present, their prices would cease to be monopoly prices altogether independent of the cost of production. An analogous state of things subsists with regard to land; we may continue, or we may cease from, reclaiming land from bog or sea; we may continue, or we may cease from, making new railways and other means of communication; we may continue, or we may cease from, sinking capital in draining, fencing, and manuring lands, and in supplying and maintaining farm buildings: and if we cease altogether from activity in these respects not only will the units of efficiency in land cease to increase, but they will begin very rapidly to diminish.

Do we not here approach the heart of our diffi- 
culty? If the received economic definitions of rent were adequate then indeed the received economic doctrine concerning rents not entering into the determination of prices, might be accepted.

Professor Marshall (as quoted above, $\S 27$ ) defines rent as the "Producer's surplus of a differential advantage not made by man"; as "the excess value of the return which can be got by its aid where labour and capital are applied with normal ability up to the margin of profitableness, over that which the same labour, capital, and ability, would get if working without the aid of any such advantage." This definition is sufficient when we are considering the relative values of different pieces of land; but it appears to me not to be sufficient when we are considering the total remuneration received by land, and the capital sunk in it, as an agent of production, for here not only has a large amount of the differential advantage been made by man in the past, but in the present and in the future the exact amount of efficiency available from this source will depend on man's effort, and so we get a margin of production which is not fixed either in extension or in intensity of cultivation. Shortly my contention is that in comparing one parcel of land (with its natural advantages, and 
with the capital that has been irretrievably sunk on it), with another, the advantages possessed by the one over the other may be treated (like monopolies) as being independent of the cost of production. But that if rents in the aggregate are taken they cannot be so regarded.

Professor Marshall's definition is useful in determining the reason for the payment of a certain rent by one parcel of land, when another parcel of land pays a less rent, or no rent at all, but it is, or appears to me to be, useless for determining the total reward of land as an agent of production, for it gives us no help in determining where the margin of cultivation shall be, and there is no means of determining the amount of capital and labour to be applied.

$\S 34$. My main point may be stated to be that although what is paid for the differences in the inherent efficiency of land does not, what is paid for the actual inherent, efficiency of the land does, constitute a determining element in prices, and since "rent" may be understood in the latter as well as in the former sense, it is at least misleading to say that "Rent has no part in determining the expenses of production."

In the first signification it will be observed that rent merely contemplates a comparison of values of 
different pieces of land; in the second signification it contemplates a comparison of the value of land with that of the other agents of production.

Now when we say that wages enter into the expenses of production, we mean the reward of labour in the aggregate, not the advantage in reward which a skilled labourer receives over an unskilled one.

Again when we say that profits enter into the expenses of production we mean the actual reward of the organisation of labour, not the advantage which a skilled organiser receives over an unskilled one.

And again we say that interest enters into the expenses of production meaning the actual reward for lending capital, not the advantage which some forms of capital possess over others. Why then in the name of all that is consistent should we not say that rent enters into, and has influence in determining, the expenses of production, meaning thereby the aggregate reward paid to landlords for the use of so much of their land as is at a given moment required?

$\S 35$. I believe the analogy that subsists between land and the other agents of production is a very close one, and that disturbances in the industrial equilibrium affect rents in a way which is quite similar to that in which they affect profits, wages, or interest. 
$\S 36$. Supposing for instance that in consequence of internal political disturbances bodies of labourers are expelled from one country and make their domicile in another, the aggregate reward of labour in the latter country will probably increase, but there is little doubt that the reward per unit of labour will diminish.

How is this case dissimilar from that of a country which in consequence of the invention of the locomotive is suddenly covered with a network of railways, thus vastly increasing the amount of accessible land? The aggregate rents of the country will probably increase and the reward per unit of land diminish.

These are disturbances from the normal caused from without: their occurrence though more dramatic is less habitual than that of disturbances from the normal arising from internal causes.

$\S 37$. At a given moment the total product of the world may be divided up into parts which shall represent the respective rewards of the agents of production. The clearing-house which effects this is in fact the automatic action of the competitive system; but were there an actual clearing-house we should have on the one hand paid into it the prices of all commodities, and we should have to 
pay out of it on the other rent, wages, profits, and interest, in certain definite proportions. Now it might be that a certain commodity would be found whose price would be divided up in the clearinghouse into four parts to be paid respectively to the landlords, labourers, organisers, and capitalists, in exactly the same proportions as the total shares receivable by these four controllers of the agents of production. Such a commodity we will for the moment call the typical commodity.

$\S 38$. Now if the demand of the community increases or decreases for this typical commodity no disturbance will take place in the economic equilibrium because the proportions of the distribution to be effected will not be disturbed. But the prices of most commodities will be distributable in other proportions than these. In some a larger proportion of their price than in that of the typical commodity will be apportioned to rent; these we may call land-commodities, in some a larger proportion of their price than in that of the typical commodity will be apportioned to wages; these we may call labour-commodities. Similarly we shall get others that we may call organisation-commodities, and others that we may call capital-commodities. Now suppose that a change takes place 
in the demand of the community for commodities, which increases the demand for labour-commodities concurrently with decreasing the demand for the other three sorts of commodities. Labour will at once be able to claim a larger share of reward from the clearing-house, the prices of all labour-commodities will rise and those of all other commodities will fall. With the increased reward to labour (per unit of efficiency) more labour will probably come into the market; immediately labourers will seek to increase the amounts of units of efficiency they can produce, possibly by working longer hours, or it may be (if they are working on piece-work) by working more industriously; and there will also gradually be felt a tendency to a more rapid increase of population. Ultimately something near the old equilibrium may be restored but it is probable that when the counteractive forces have had their innings the then typical commodity will be found to yield a larger share of its price to labour than its predecessor before the disturbance did.

Suppose now that there is an increased demand for capital-commodities. Capital-commodities in general will rise in price, other commodities will fall; the consequent rise in interest will be righted to a certain extent by increase in accumulation but 
as in the former instance the commodity typical at the end of the cycle of disturbance will probably be found to be one yielding a larger share of its price to capital than did the commodity that was typical before the disturbance.

All this is but another way of saying that wages (in the aggregate) and that interest (in the aggregate) each have a voice in determining the expenses of the production of commodities.

$\S 39$. Now when we come to examine land-commodities is there any essential difference which will justify us in saying that rent (in the aggregate) unlike wages, unlike interest, unlike profits, does not have a voice in determining the expenses of the production of commodities? On the contrary the circumstances seem to be precisely similar.

If we suppose an increased demand for landcommodities there will be a general rise in prices of such, but the consequent rise in rents will be partially counteracted by an extended margin of production (i.e. less fertile and less accessible land will be brought into cultivation). Similarly to what occurred in the other cases the new typical commodity that takes the place of the old one will have in its composition a somewhat larger proportion of rent than the one it has displaced; but to justify 
the doctrine that aggregate rents do not partly determine the prices of commodities, but are wholly determined by them, it would be necessary to have a state of things in which there was no tendency to recovery towards the composition of the first typical commodity. The fact that the recovery does to some extent take place witnesses to the ability of rent to take its part in the settlement of prices. It is not the limp incapable thing that we are persuaded to believe, greedily licking up what is thrown to it, but impotent to affect the greatness or the smallness of the quantity thrown.

$\S 40$. My conclusion then is that it is not true to say that "lent does not enter into the expenses of production" except in a non-natural interpretation of the phrase, which would make it equally true to say that wages, that profits, and that interest do not do so.

$\S 41$. We have now to consider whether the case under investigation is in any way affected by the law of diminishing returns. The law is of the first importance in connection with the subject, for without its operation rent might be non-existent. As Ricardo points out, no farmer would require more than one field, and on that he might raise whatever amount of crops he required by the simple expedient of applying continual successive "doses" of capital. 
The law of diminishing returns demonstrates then the necessity of rent. Does it do more than this? Does it demonstrate that rent has no part in determining prices? At first sight it seems as if it might; we have seen how the valuable characteristics of land can be brought into existence by man's exertions, but it may be urged that although land can be made more fertile and more accessible it cannot be made naturally advantageous; the start can be made up but it cannot be given, and it may be that the advantageous start is the valuable quality which cannot be brought about by man's effort. But this is like saying that a woman who made stockings by hand could do nothing to affect the market of those made by machinery; if they were practically one and the same article they would compete against each other even though the manufactory started with the advantage of turning out hundreds of pairs to every single pair hand-knitted by the woman.

$\S 42$. The law of diminishing returns does not necessarily differentiate land from the other agents of production. That law points to the fact that where the community has an effective desire to get more out of the land than it has previously done, it will do so at greater proportionate cost. But just the same phenomenon is observable (though not to 
such a large extent) when larger drafts are made on other agents of production. A considerably increased demand for capital, although it would encourage saving, would have a tendency permanently to raise the rate of interest, that is to say the community to secure the additional capital would have to make a sacrifice larger in proportion than that which they had to make previously, to secure the smaller amount of capital, or in other words the law of diminishing returns would here be found to be in force. Even in the case of labour, though some maintain that a stimulated demand would be met by an increase of population that would make units of efficient labour as plentiful in proportion to the demand as before, it is very doubtful whether this can be fully established. Mill at any rate was of opinion that a sudden raising of wages would increase the labourers' "standard of living" and that it would therefore not be followed by an increase of population sufficient entirely to counteract the rise. But if Mill was right we should only succeed in getting our increased supplies of labour on terms that would be more disadvantageous to the whole community than before; and the law of diminishing returns would be found to be in operation here also.

$\S 43$. As a final consideration I would suggest 
our examining what the effect would be of the imposition of a tax on rent-paying land. A tax on such land or on rents would affect the general prices of commodities, for it would prevent the units of efficiency of land from being brought into service to the same extent. A certain amount of land that before would have been utilised for industrial production will be converted into, or will remain as, garden, park, or grouse-moor, or will not be reclaimed from the sea by embankment, or from bog by drainage, or from inaccessible wastes by railways.

A $\operatorname{tax}$ on rents would hinder the investment of capital in the permanent improvement of land, because other forms of investment would become relatively more profitable, consequently it would diminish the efficiency of land, and raise the price of all commodities of which land was one of the agents of production.

If on the other hand the tax be levied not on rents but on acreage of rent-paying land, prices of commodities will still be affected though by rather a different train of cause and effect. There will be no check on the investment of capital in the permanent improvement of land, but there will be a tendency to decrease the area under cultivation, and in this way the margin of cultivation will be 
contracted. The extension of the land will be diminished, but to counteract the consequent diminution of produce the land still kept under cultivation will be made to yield more intensively. But the additional capital lavished on the smaller area of land will, in consequence of the law of diminishing returns, yield a smaller return than the same amount of capital expended on the larger area would do ; consequently the price of produce will rise.

$\S 44$. It appears therefore that however a tax on rent-paying land is levied it is calculated to affect prices, or in other words that a part of it will be paid by the general consumer. But the proposition that rents do nothing to determine prices can be upheld only on the supposition that the whole of the differential advantage arising from the use of land goes into the pockets of the landowners. If this were so they would be powerless to compel consumers to pay a part of a land-tax; the consumers would have no interest in the matter and would have nothing to gain by contributing. The fact that they do contribute shows that they have a stake in the matter, and that the general rate of rents, like the general rate of interest, of wages, or of remuneration of organising power, takes its part in determining the prices of commodities. 


\section{CHAPTER V}

Labour is neither limited for its reward to a WageFund, nor is it entitled to the residuum of a varying Product of Industry. Wages (like Rent, Intercst, and Entrepreneur's Profits) are. a Varying Proportion of a Varying Product of Industry. Wages Problems worked out on this basis.

$\S 45$. The proposition above stated is in effect the conclusion at which we arrived at the beginning of Chapter IV., and that which we found to be in substantial agreement with Professor Marshall's book Principles of Economics, except that that work treats rent as being on a different basis to that on which wages, interest, or profits rest. We may conclude then that the product of industry will be divided in certain proportions between rent, interest, profits and wages, and it will be instructive if we endeavour to work out wages problems on this basis. 
The particular numerical proportions we take will be perfectly arbitrary and of course no conclusions can be drawn from the actual numbers. But where in our analyses we are able actually to show that there will be an increase or a decrease in any particular, about such increase or decrease it will be permissible to argue. The actual amount of increase or decrease supposed will be arbitrary; on that therefore we must of course base no conclusions.

$\S 46$. Let us take the following, which we will call Case No. 1, as a standard for comparison with other circumstances :-

Case No. 1.

During an imaginary standard year :-

10 numerical Units of Labourers supply 10 Units of Labour.

The total Product of Industry $(x)=1000$ Units of Products.

$x$ is divided amongst the Four Agents of Production.

Rent (which we will signify by the letter $R$ ) is the share of the Landlords.

Interest (which we will signify by the letter I) is the share of the Capitalists.

Profit (which we will signify by the letter P) is the share of the Entrepreneurs.

Wage (which we will signify by the letter W) is the share of the Labourers. 
We will suppose

10 Units of Land ${ }^{1}$ to be industrially employed and that $R=80$ Units of Products.

10 Units of Capital to . be industrially employed and that

$\mathrm{I}=160$ 9

10 Units of Organising Power to be industrially employed and that

10 Units of Labour to be industrially employed and that

$$
\mathrm{P}=160 \quad, \quad, \quad,
$$

$\mathrm{W}=600 \quad, \quad "$

1000

The average wages received by 1 numerical Unit of Labourers will be 60 Units of Products.

In the case supposed the total product of industry is 1000 units, out of which a share of 600 is secured by labour.

$\S 47$. Now suppose we take another year, which differs from the standard year in respect of the population, which has doubled in numbers. To estimate the effect on the reward of labour, we must examine first the effect that will be produced on the number of units of the total product, and

1 A Unit of Land is measured by its area multiplied into its fertility, accessibility, and other valuable qualities. 
secondly on the share of that product to be secured by labour.

$\S 48$. Now with regard to the first, we have already seen (chap. i. $\$ 4$ ) that efficiency (that is to say increase or decrease of the total product) is not always proportionate to the increase or decrease of the effort exerted, or abstinence exercised, by or through any particular agent of production. Where efficiency increases in larger proportion than the increase of the effort exerted, the law of increasing returns is said to be in operation, in converse circumstances, the law of diminishing returns.

Now the circumstance of a doubling of population would undoubtedly be pronounced by many economists as a case where the law of diminishing returns would, come into operation. They would submit that the doubling of population cannot be considered in relation to labour power alone. True the amount of effort that can be exercised by labour is doubled, for there are twice as many arms, and legs, and sets of muscles; but there are also twice as many stomachs; accordingly double the amount of food must be raised, and the additional quantity will be produced under less advantageous circumstances, for less fertile land will have to be brought into cultivation, or the land already in 
use will have to be more intensely cultivated, and will give a less proportionate yield.

The reasoning is perfectly just; without doubt the law of diminishing returns will be operative. But what is by no means clear is that the law of increasing returns will not also be operative, and still more powerfully, so that taking the balance of matters we shall have to say that the law of increasing, and not that of diminishing, returns is in operation.

Mr. Edwin Cannan in a recent number of the Economic Journal (March 1892, "The Origin of the Law. of Diminishing Returns") says :-

"Few historical facts can be better established than that with the progress of wealth and population in the present civilised world, the labour of providing raw produce has been performed by a steadily decreasing proportion of the whole population, and till some one brings forward statistics to show that an agricultural labourer now employed at the margin of cultivation actually produces less wheat or beef than his predecessor in the time of King Alfred, we may take this as sufficient proof that the returns have increased, and not diminished." 
It would appear then that though the world is constantly labouring under increased economic disadvantages by reason of there being an additional number of stomachs to be supplied with food, which can only be satisfied with augmenting difficulty, it is not in fact experiencing greater difficulty in existence. This points to there being some compensatory force at work which admits of the law of increasing returns coming into operation. What then is the great source of increasing return from like employment of effort? Surely new thought applied to the industrial system. From thought results discovery and invention,- discovery in the mechanical world, discovery in the chemical world, discovery in the electrical world, discovery in the geographical world; from thought too results better application and organisation of the already existing industrial forces. It is thought that results in giving men the power of commanding better returns from the exercise of their energies; and the dwelling-place of thought is the human brain.

To my apprehension it is not clear that an increase in the number of the stomachs of even the labouring classes does more to hinder the material welfare of mankind, than does the increase in the 
number of their brains to further it. But the case before us is an increase in the whole population, and we may therefore assume an increase in the number of entrepreneurs (whose brains provide much the most fertile fields from which to reap thought applicable to industrial concerns), as well as in that of the labouring population. The life of a great mechanical discoverer like James Watt, or of a great organiser of labour, does much more to increase the Product of Industry in proportion to population, than the advent of many thousands of ordinary lives does to decrease it.

It would be a difficult task to attempt to compute what increase or diminution of the total product would follow on alterations in the aggregate amounts of the various agents of production in industrial use, or in alterations in the proportions borne by one or more of the agents of production to others.

We however know that increase of cultivation of land either in area or intensity brought about by increased pressure of population, will yield a proportionately decreasing return, but at the same time we observe that this identical increased pressure of population carries with it an increase of brain power and that this results in an increasing industrial 
return. (We may note by the way that one of the forms of activity pursued by brain power results in the opening up of fresh land in new countries. An increase of land brought about thus-consequent that is to say not on the larger number of stomachs, but on the larger number of brains,-yields not a decreasing, but an increasing return.)

An increase of population then would affect our four agents of production in some such way as the following :-

Land would follow the law of diminishing returns so far as greater pressure was exercised on areas formerly available (whether actually in industrial use or not):

but would follow the law of increasing returns so far as fresh areas were rendered available.

Similarly capital if expended on the land, or on industrial enterprises in operation before the increase of population, would follow the law of diminishing returns :

but when the ingenuity of man opens up fresh fields for its exercise, they are in a large number of cases more profitable fields also.

So much for the two inanimate agents of production ; their position is dependent on man, and follows 
the law of diminishing, or that of increasing, returns according as to whether in man the wants of the stomach or the creations of the brain obtain the leadership.

We must also consider the animate agents of production. We have classified the industrial powers of mankind under two of these,-Labour Power, and Organising Power. It would however be a mistake to suppose that human beings can be very rigidly separated into those that are to be regarded as labourers, and those to be called entrepreneurs. The labourer pure and simple is the man who works as an animal works, not necessarily without intelligence, but without initiative thought. $\mathrm{He}$ for example, exercises the muscles of his arms and legs in digging, in the same sort of way that a horse exercises its muscles in pulling a plough; or possibly he is a clerk whose employment is mechanical copying of letters, or mechanical adding of ledgers. Very little human work however is so closely assimilated to that of the beasts as properly to be regarded as pure labour power, without any admixture of organising power. Probably the nearest approach to it is to be found amongst the labour of slaves and serfs; but as we pursue our examination higher in the industrial scale we find 
that the entrepreneur element in man assumes more importance. It is not merely that a certain number of picked men will become actually in the main organisers of the labour of others, but that ingenuity, administrativeness, contrivance, and invention of new methods, are continually being exercised in connection with the individual's own particular work.

In the entrepreneur class there is on the other hand a certain admixture of routine work with which activity of brain has little to do. On the whole however amongst the entrepreneurs the importance of the brain vastly outweighs that of the stomach; and it cannot confidently be said that amongst those who may roughly be classed as labourers the importance of the stomach outweighs that of the brain.

But it is on this balance of power between the stomach and the brain in the animate agents of production that depends the predominance when increased quantities of land and capital (the inanimate agents of production) are used, of the law of diminishing returns, or of the law of increasing returns, as the case may be. Is not the explanation of how it is that in the opinion of Mr. Cannan the returns of industry have not diminished since the times of 
Alfred the Great, that brain has kept pace with stomach ? ${ }^{1}$

The problem of the actual effect on the total product of industry of an increase of population is one of such practical difficulty to determine, that I incline to assume in the first place an increase of product proportionate to the increase of population, that is to say that the law of diminishing returns which would be operative in some respects would be counteracted by the law of increasing returns which we see come into force in others. The assumption (which for the sake of brevity I will in the remainder of this chapter call the Assumption of Proportionate Variation) is one of considerable magnitude, but one which we are I think justified in making in the absence of any reasonable grounds for assuming variation either in the one direction or the other. Such grounds would necessarily be based for the most part on historical evidence, and the problem is rendered more difficult when we endeavour to establish a standard of equal effort or abstinence applicable to different centuries. It is not for

1 May we not be helped to the often sought definition of Civilisation, so far as industrial matters are concerned, by remembering the connection between man's intellectual power, and his command over the industrial forces? The "March of Civilisation" corresponds with increase of brain power, one of the results of which is to bring into operation the law of increasing returns. 
instance always easy to bring it down to terms so comparable as the muscular effort needed to convey a given weight a given distance without the aid of machines. But even were the common measure found and applied, we should still have to assess the comparative appreciation of the rewards secured. Possibly for example "The Roast Beef of Old England" would find more, and literature find less, general appreciation in the time of King Alfred than they respectively do now.

If then we make the assumption of proportionate variation we must remember that we are making one which may all the time be vitiating the results of our problems, and we must certainly be prepared to abandon it if in any particular case it can be shown that disproportionate variation is to be expected either in the one direction or the other.

$\S 49$. But from the difficult attempt to estimate the effect that will be produced on the number of units of the total product we must now turn, and endeavour to fix the share of that product which will be secured by labour.

If the doubling of the population has taken a considerable period of time and if intellectual development has progressed commensurately and we assume "Proportionate Variation" we might 
possibly arrive at simply a doubling of all the numerical factors of our problem; new countries would have been discovered, new capital amassed, and new organisers of industry would have come to the front: the rates of rent, interest, profits, and wages, would remain unchanged :-

§50. Case No. 1 .

Standard Year.

Product $=1000$

10 Units of Land . $R=80$

10 Units of Capital $I=160$

10 Units of Organ-

ising Power . $\mathrm{P}=160$

10 Units of Labour $\mathrm{W}=600$

1000

The average wages received by a numerical Unit of Labourers will be 60 .
Case No. 2.

The Population hassteadily increased till it is now double what it was in the Standard Year.

Assuming Proportionate Variation.

$$
\text { Product }=2000 \text {. }
$$

20 Units of Land $R=160$ 20 Units of Capital $I=320$ 20 Units of Organ-

\begin{aligned} & ising Power $\mathrm{P}=320 \\ & 20$ Units of Labour $\mathrm{W}=1200 \\ &$\hline 2000\end{aligned}

The average wages received by a numerical Unit of Labourers will still be 60 .

$\S 51$. Suppose however that the doubling of the population takes place under circumstances quite different from these,results from a sudden influx of low-grade unintelligent labourers. We shall now no longer be able 
to postulate "Proportionate Variation," for brain will not keep pace with stomach. The total product will not be doubled. Let us suppose that it is increased to 1800 units. The commodities which will at once be rendered cheaper will be those the quantity of which can be increased by employing more labour, without employing more land, capital, or organising power. But though the community may be able to absorb a larger proportion than they previously did of such in consideration of their being cheaper, they will not wish to receive all that is saved by the cheapening of this class of commodities in a quantitative increase thereof. The proportion of the various necessities and pleasures of life will only partially remodel itself in consideration of the new conditions, and other classes of commodities also will be in more demand than before, though possibly the increase of demand for them will not be so great as for the class of what we called in $\S 38$ "Labour-commodities." Nevertheless an actual increase of organisation and supervision will be demanded from the entrepreneur; this will mean that men formerly on or below the border-land of no profits will be pressed into the service, and that those who were formerly making some profits, will now make more. More capital will be required, and to bring it into industrial 
service, a higher rate of interest must be paid. More land may have to be taken into cultivation, and culture generally be rendered more intense; the margin of cultivation will be extended, and consequently rents will be increased.

Our problem may then not improbably assume some such form as this:-

Case No. 1.

Standard Year.

$$
x=1000
$$

10 Units of Land at Rent of 8 Units.

10 Units of Capital at rate of Interest of 16 Units.

10 Units of Organising Power.

Profit at rate of 16 Units.

$$
\begin{aligned}
\mathrm{R}=10 \times 8 & =80 \\
\mathrm{I}=10 \times 16 & =160 \\
\mathrm{P}=10 \times 16 & =160 \\
\mathrm{~W} \quad & =600=10 \times 60 \\
&
\end{aligned}
$$

The average wages received by a numerical Unit of Labourers will be 60 .
Case No. 3.

Population doubled by sudden influx of low-grade unintelligent Labour.

Product increased by 800 Units.

$$
x=1800
$$

Increased rates of Rent, Interest, and Profits.

15 Units of Land at Rent of 9 Units.

15 Units of Capital at rate of Interest of 18 Units. 15 Units of Organising Power. Profit at rate of 18 Units.

$$
\begin{aligned}
\mathrm{R}=15 \times 9= & 135 \\
\mathrm{I}=15 \times 18 & =270 \\
\mathrm{P}=15 \times 18= & 270 \\
\mathrm{~W} \quad & =\frac{125=20 \times 56 \frac{1}{4}}{1800}
\end{aligned}
$$

The average wages received by a numerical Unit of Labourers will be 561 . 
In the case supposed, we see the reward of the average labourer decreased in the ratio of 60 to $56 \frac{1}{4}$.

It will be observed that this suppositious case does not satisfy Professor Walker's contention that all the additional product resulting from increased effort on the part of the labourer, necessarily accrues to him ; we see reasonable grounds for supposing that some of it will be apportioned to $\mathrm{R}, \mathrm{I}$, and $\mathrm{P}$.

On the other hand the case supposed is equally far from satisfying the Wage-Fund theory, according to which wages per numerical unit of labourers (on the supposition that 50 per cent more capital was drawn into industrial use), would have sunk 25 per cent from what they were in the standard year, that is to say they would have been reduced to 45 units of products.

We have been able to show a suppositious case in which the wage per capita, although diminished, is not diminished to anything like this extent, and though it is true that the figures are taken arbitrarily that does not show that the case is impossible or necessarily false; but as it is inconsistent with the wagefund theory, it is necessary from their point of view that the supporters of that theory should demonstrate that it is logically impossible.

$\S 52$. In the above case an increase in population 
leads to a decrease in the wages received per capita. But supposing the increase of population to be accompanied by a greatly improved system of education, or by increased efficiency of work consequent on the division of labour being more perfectly carried out (as is sometimes the case in new countries), these conditions may be reversed, and an increase in population may lead to an increased proportionate product. In such a case a SMALLER proportionate contribution may perhaps be paid to the other agents of production in the aggregate, and the increased population will under such circumstances actually result in inereased wages per capita :-

Case No. 1.

Standard Year.

$$
x=1000
$$

Case No. 4.

Doubling of the Population accompanied by improved system of education and better division of labour.

Product increased by 1200 Units

$$
x=2200
$$

Increased rates of Rent and Interest, but the same rate of Profit.

[Under the state of things supposed, there will be many more able and willing to join the ranks of the entrepreneurs than before. On the 
other hand, there will be such a large increase in the amount of organising power required that it will not be safe to predict that there will be either diminution or increase in the rate of Profit.]

$$
\begin{aligned}
\mathrm{R}=10 \times \quad 8 & =80 \\
\mathrm{I}=10 \times 16 & =160 \\
\mathrm{P}=10 \times 16 & =160 \\
\mathrm{~W} \quad & =600=10 \times 60 \\
&
\end{aligned}
$$$$
\mathrm{R}=15 \times 9=135
$$$$
\mathrm{I}=15 \times 18=270
$$$$
\mathrm{P}=\mathbf{2 5} \times 16=400
$$

WV

$$
=\frac{1395}{2200}=20 \times 69 \frac{3}{4}
$$

The average wages received by a numerical Unit of Labourers will be 60 .

The average wages received by a numerical Unit of Labourers will be $69 \frac{3}{4}$.

$\S 53$. If we next take the inverse case, that of a population diminished by pestilence to one half its former numbers, the probable effect in an old country will be converse to that shown in Case No. 3 ; there will be a very large increase of the wages paid per capita to labour.

This is illustrated by the historical case of the enormous rise in wages of labour which succeeded the depopulation of England by the Black Death :- 
Case No. 1.

Standard Year.

$$
x=1000
$$

$$
\begin{aligned}
\mathrm{R}=10 \times 8 & =80 \\
\mathrm{I}=10 \times 16 & =160 \\
\mathrm{P}=10 \times 16 & =160 \\
\mathrm{~W} \quad & =600=10 \times 60 \\
&
\end{aligned}
$$

The average wages received by a numerical Unit of Labourers will be 60 .

\section{Case No. 5.}

Population halved by pestilence.

The community will be supplied with land, with some forms of capital, and probably with entrepreneur power in a proportion larger to population than before. The total product will not then be diminished by half with the halving of the population:-

$$
x=700
$$

Land will fall out of cultivation to some extent, and rents will fall; it will be difficult to withdraw fixed capital immediately, interest therefore will seriously diminish. The entrepreneur class will not be affected by pestilence so much as the labourers, there will be more than half of them left, and there will be some diminution of profit:-

$$
\begin{aligned}
\mathrm{R}=7 \times 6 & =42 \\
\mathrm{I}=9 \times 8 & =72 \\
\mathrm{P}=6 \times 15 & =90 \\
\mathrm{~W} \quad & \underline{496}=5 \times 99 \frac{1}{5} \\
& \underline{700}
\end{aligned}
$$

The average wages received by a numerical Unit of Labourers will be $99 \frac{1}{5}$. 
Wages per capita will therefore have risen in the ratio of 60 to $99 \frac{1}{5}$.

$\S 54$. Another historical instance (noticed above chap. ii. $\S 18$ in connection with Cairnes's argument) is the change in the conditions of cultivation in Ireland after the famine, resulting in the reduction of the population from 8 to $5 \frac{1}{2}$ millions.

Now here the new state of things, since it is brought about by the landlords themselves, may be assumed to be better for them than the old; their rent-roll will be increased; and the rates of interest and of profits will not sink, or the capitalists and entrepreneurs would not continue to supply the required capital and organising power. How is it that it is so much worse for the labourer?

Is it because the landlord secures a much larger number of units of the product of industry than formerly accrued to him? This is an extremely improbable suggestion; if there was an enormous advantage to be reaped by the landlords from an economic change which they themselves could initiate by "clearances" and like action, would they not have made it long before? The much more probable solution is that though the landlord secures a slightly better position, the main injury to the position of labour results not from this, but from a serious diminution in the total product of industry. 
The landlord finds that he can get a somewhat better rent for his land as pasture land, than if let under tillage ; but the employment of capital, organising power, and labour, is much curtailed by the change, and as might be expected, the total product is much diminished in consequence. The surplusage of these other three agents of production goes to other countries; in the case of labour the emigration takes place chiefly to America.

Case No. 1.

Let us suppose our Stand- Ireland as a pasture country. ard Year to represent Ireland under tillage.

10 Units of Land

$$
R=10 \times 8=80
$$

10 Units of Capital

$$
I=10 \times 16=160
$$

10 Units of Organ-

$$
\begin{aligned}
& \text { ising Power } \\
& P=10 \times 16=160
\end{aligned}
$$

10 Units of Labour

$$
\mathrm{W}=10 \times 60=\frac{600}{1000}
$$

Total Product- $(x)=1000$
10 Units of Land

$$
\mathrm{R}=10 \times 9=90
$$

7 Units of Capital

$$
I=7 \times 16=112
$$

7 Units of Organ-

$$
\text { ising Power }
$$$$
\mathrm{P}=7 \times 16=112
$$

7 Units of Labour

$$
\mathrm{W}=7 \times 60=\frac{420}{734}
$$

Total Product- $\overline{\overline{(x)=}} 734$

The average wage received by a numerical unit of labourers remains 60 ; the surplusage who are unable to get this old rate of remuneration in Ireland emigrate to America, till only the requisite numbers for the new conditions are left.

[In reality of course there would be a certain amount of unwillingness to emigrate, and consequent inertia, and 
wages in Ireland would therefore sink somevhat below their old level; but on the whole labour will tend to emigrate till the wage per capita under the new state of things nearly equals that under the old.]

$\S 55$. But what would have happened in Ireland if there had been no possibility of emigration for the labourers? Well then they would have been compelled to accept such wages as would make it more profitable to the landlords to continue industry under the old system, than to initiate the new one.

In order to secure that the landlords shall not introduce the new system of agriculture they must be given a larger rent for their land than they receive in Case No.6. Let us suppose $R$ to equal 95, and $I$ and $P$ to be the same as in Case No. 1. Then comparing once more with our Standard Year we get the following result :-

Case No. 1.

Standard Year.

$$
x=1000
$$

10 Units of Land

$$
\begin{aligned}
& \mathrm{R}=10 \times 8=80 \\
& \mathrm{I}=160 \\
& \mathrm{P}=160 \\
& \mathrm{~W}=600 \\
& 1000
\end{aligned}
$$

\section{Case No. 7.}

Ireland compelled to adhere to the old state of cultivation because emigration is impossible.

$$
x=1000
$$

10 Units of Land

$$
\begin{aligned}
R=10 \times 9 \frac{1}{2} & =95 \\
I & =160 \\
\mathrm{P} & =160 \\
\mathrm{~W} & =\frac{585}{1000}
\end{aligned}
$$

The average wage received by a numerical Unit ceived by a numerical Unit of Labourers will be 60 . of Labourers will be $58 \frac{1}{2}$. 
We are now in a position to examine some contemporary labour problems :-

$\S 56$. Let us suppose that the average hours of labour are at present 10. Taking our Standard Case No. 1 to represent the present state of things, what would be the effect of an alteration to an 8 hours' labour day?

First of all it is claimed that there will result a larger proportion of efficient labour so that we are not justified in supposing the units of labour power to be reduced from 10 to 8 , but only say from 10 to $8 \frac{1}{2}$. We are however now faced by a new element in our problem. Hitherto we have had to deal with muscular power proportionate to the numbers to be fed; an increase of population, in our previous cases, brought more stomachs to be fed, but it also brought into action more sets of muscles. True, the newly added sets of muscles did not ordinarily work to so great advantage as the old ones, and hence the returns resultant from their efforts decreased; still there were returns. But now we are faced with an increase of stomachs in relation to labour power in the ratio of 10 to $8 \frac{1}{2}$ without any additional returns coming in at all. In the difficulty that before presented itself to us, where was our refuge? We found that the increasing disabilities, under which labour power operated, were in the long run compensated, if not 
more than compensated, by the increasing advantages secured by additional brain activity. Consequently we have, as regards the general progress of the world, been able to assume variation of total product proportionate to variations of labour power, consequent on variations of population. But if it is demanded of brain power that it shall make up the deficiencies of decreased labour power consequent on the curtailment of the hours of labour, the case is different, for there is immensely more leeway to make up, and activity of brain on a much more highly increased scale will be required. Is it likely that this will be forthcoming? The extant number of brains is not (as before) increased, but there comes with more leisure a possibility of better education, more thought, and a better rested brain ; whether however less fully engaged time will be actually accompanied by increased brain power depends entirely on how the former is used. It is conceivable that if the best possible use were made of the increase of leisure such marvellous improvement in industrial methods might take place, that we should be justified in assuming actual proportionate variation, which in the present instance would mean that there was no reduction of product, that it, like population, remained constant. But the more probable result is that 
though increased brain power will be stimulated, it will not be able to meet in its entirety the demand made upon it, and that we shall have the total product neither maintained at 1000 , nor reduced to 850 but lying somewhere between the two, say for example's sake at 910 units.

Our case is now somewhat similar to Case No. 5 . Labour becomes scarce and it is likely that in the dividing up of the total product of industry the shares $\mathrm{R}, \mathrm{I}$, and $\mathrm{P}$ will sink proportionately to $\mathrm{W}$. If however we consider the case of a single country, capital, which has great mobility, will be proportionately, though gradually, withdrawn (fixed capital it is true is not easily withdrawn, but it will not berenewed); what remains will be paid at the same rate of interest as before. Entrepreneurs will also to some extent withdraw themselves. - But land which has little mobility will only to a certain extent fall out of cultivation, though rents will fall. We shall then probably see some such results as the following :-

Case No. 1.

Standard Year

(Ten Hours worked)

10 Numerical Units of Labour supply 10 Units of Labour Power.

$$
x=1000
$$

Case No. 8.

Eight Hours of Labour introduced.

10 Numerical Units of Labour supply $8 \frac{1}{2}$ Units of Labour Power.

$$
x=910
$$


10 Units of Land

10 Units of Capital

10 Units of Organising Power

$$
\begin{aligned}
\mathrm{R}=10 \times 8 & =80 \\
\mathrm{I}=10 \times 16 & =160 \\
\mathrm{P}=10 \times 16 & =160 \\
\mathrm{~W} \quad & =600=10 \times 60 \\
&
\end{aligned}
$$

The average wages received by a numerical Unit of Labourers will be 60 .
9 Units of Land at a much diminished rent.

8 Units of Capital at same rate of interest.

9 Units of Organising Power at somewhat diminished rate of Profits.

$$
\begin{aligned}
\mathrm{R}=9 \times 6 & =54 \\
\mathrm{I}=8 \times 16 & =128 \\
\mathrm{P}=9 \times 15 & =135 \\
\mathrm{~W} & =\frac{593}{910}=8 \frac{1}{2} \times 69 \frac{13}{17}
\end{aligned}
$$

The average wages received by a numerical Unit of Labourers will be $59 \frac{3}{10}$.

The per capita wage is therefore diminished in the ratio of 60 to $59 \frac{3}{10}$, that is to say the labourer receives less wages for less work, but per hour, he is paid better than he was before (otherwise the per capita wage would have been reduced not to $59 \frac{3}{10}$, but to 48). Per unit of labour power exerted he is also paid better than he was before (otherwise the per capita wage would have been reduced not to $59 \frac{3}{10}$ but to 51 ).

The actual improvements in wage secured are per hour in the ratio of 60 to $74 \frac{1}{8}$

$$
\text { (i.e. } \left.\frac{600}{10}: \frac{593}{8}\right) \text {, }
$$


per unit of labour power exerted they are in the ratio of 60 to $69 \frac{13}{17}$

$$
\text { (i.e. } \left.\frac{600}{10}: \frac{593}{8 \frac{1}{2}}\right) \text {. }
$$

Something like the above is a very possible result of an effective eight hours' movement. The labourers would not receive per head as much wage as before, or, in other words, they would be spending some of their former wage in the luxury of leisure. If the leisure is well spent it is difficult to imagine any luxury the enjoyment of which is likely to be fraught with more benefit; indeed without it, it is difficult to see how the working classes can participate in any large degree in the intellectual enjoyments of life, or even fit themselves for the exercise of the political power with which they are entrusted. The writer of Ecclesiasticus says :-

"The wisdom of a learned man cometh by opportunity of leisure; and he that hath little business shall become wise."

"How can he get wisdom that holdeth the plough, and that glorieth in the goad; that driveth oxen; and is occupied in their labours; and whose talk is of bullocks?" 
"They" (that is the unleisured labourers) "shall not be sought for in public counsel, nor sit high in the congregation: they shall not sit on the judges' seat, nor understand the sentence of judgment: they cannot declare justice and judgment, and they shall not be found where parables are spoken" (chap. xxxviii., verses 24 , 25 , and 33 ).

It is observable that the author of this apocryphon seeks to point out that whilst the smith, the carpenter, the potter, the maker of seals, the agricultural labourer etc. "maintain the state of the world," they are quite unfit to take part in its political guidance. When the verses were quoted by Burke a century ago ("Reflections on the Rcvolution in France"), it does not seem even then to have occurred to him that any other gloss could be put on them. It is remarkable evidence of the progress of democratic sentiment during this century that to nine minds out of ten reading these texts to-day, the suggestion will be made not of the necessity of excluding the democracy from political life, but of the exigency of the demand made by mechanics and labourers for leisure.

The desirability of more leisure for the working classes has almost ceased to be a controverted ques- 
tion, but what they must now ask themselves is, "Can we afford it?"

$\S 57$. Now although Case No. 8 may be a probable result of an effective "eight hours' movement, there are others that are also possible.

In Case No. 8, greater brain power increased the proportion of the total product to the supply of labour power. It is conceivable that that increase would have been greater than there supposed. Again by the restriction of the hours, and therefore of the supply of labour, the proportions of $R, I$, and $P$ to IV were altered and it is possible that they might be altered still more in the same direction.

Case No. 8.

Eight Hours of Labour introduced resulting in a higher wage paid per hour, and also in a higher wage per unit of Labour Power exerted, but in a lower wage per capita.

$$
\begin{aligned}
x & =910 . \\
\mathrm{R}=9 \times \quad 6 & =\overline{54} \\
\mathrm{I}=8 \times 16 & =\frac{128}{\mathrm{P}} \\
\mathrm{P}=9+15 & =135 \\
\mathrm{~W} \quad & \frac{593}{910}=8 \frac{1}{2} \times 69 \frac{13}{17}
\end{aligned}
$$

Case No. 9.

Eight Hours of Labour introduced resulting in a higher wage per capita, as well as per hour and per unit of Labour Power exerted.$$
x=920
$$$$
\mathrm{R}=8 \times 5=\overline{40}
$$$$
I=7 \times 16=112
$$$$
\mathrm{P}=8 \times 14=112
$$$$
\text { IV }
$$$$
=656=8 \frac{1}{2} \times 77 \frac{3}{17}
$$$$
920
$$ 
The average wage received by a numerical unit of labourers will have decreased in the ratio of $60: 59 \frac{3}{10}$.
The average wage received by a numerical unit of labourers will have increased in the ratio of $60: 65 \frac{8}{10}$.

In suclı a case not only would the labourer be paid better wage per hour, and better wage per unit of labour power exerted, than before, but he would actually receive a better per capita wage in the proportion of $65 \frac{6}{10}$ to 60 . So far from having to consider whether he could afford leisure, he would improve his position by the very act of working fewer hours.

$\S 58$. On the other hand a diametrically opposite result might ensue if the total product were less than we supposed in Case No. 8 and if the proportions of $\mathrm{R}, \mathrm{I}$, and $\mathrm{P}$ to $\mathrm{W}$ were also diminished to a less extent. It might indeed happen that one or more of the agents of production was affected in the opposite direction. Supposing for example that the restriction of the supply of labour led to a larger employment of machinery and a consequent greater use of fixed capital, we might get a case of this description :-

Case No. 8.

Eight Hours of Labour introduced resulting in a higher wage paid per hour, and also
Case No. 10.

Eight Hours of Labour introduced resulting in a lower wage per capita and also in 
in a higher wage per unit of Labour Power exerted but in a lower wage per capita.

$$
\begin{aligned}
x & =\frac{910}{54} \\
\mathrm{R}=9 \times 6 & =\overline{54} \\
\mathrm{I}=8 \times 16 & =128 \\
\mathrm{P}=9 \times 15 & =135 \\
\mathrm{~W} \quad & \frac{593}{910}=8 \frac{1}{2} \times 69 \frac{13}{17}
\end{aligned}
$$

The average wage received by a numerical Unit of Labourers will have decreased in the ratio of 60 to $59 \frac{3}{10}$. a lower wage paid per hour, and per unit of Labour Power exerted.

$$
\begin{aligned}
x & =900 \\
\mathrm{R}=9 \times 7 & =\overline{63} \\
\mathrm{I}=15 \times 16 & =240 \\
\mathrm{P}=9 \frac{1}{2} \times 16 & =152 \\
\mathrm{~W} & =\frac{445}{900}=8 \frac{1}{2} \times 52 \frac{6}{17}
\end{aligned}
$$

The average wage received by a numerical Unit of Labourers will have decreased in the ratio of 60 to $44 \frac{1}{2}$.

Here the per capita wage is diminished to such an extent (i.e. in the ratio of 60 to $44 \frac{1}{2}$ ) that the labourer actually gets less payment per hour of work done (in the ratio of 48 to $44 \frac{1}{2}$ ) even though he gives more labour power per hour than before. In such a case the labourer would be paying for leisure at a greatly enhanced price.

[If it happened that W was reduced to 450 he would be receiving a slightly better wage per hour (i.e. in the ratio of $48: 50$ ) but a slightly worse wage per amount of labour power exerted (i.e. in the ratio of 51 to 50$)$.]

$\S 59$. The effects of an eight hours' movement on wages cannot be arrived at on a priori grounds; nor 
is it safe to argue too positively from precedent in such a matter; it is for instance quite conceivable that in a movement for a reduction of the hours of labour from 10 to 9 , circumstances might exist, and results ensue, similar to those in Case No. 8, or Case No. 9 , but that if a successful issue were followed by a movement for a further reduction of hours from 9 to 8 , circumstances analogous to those in Case No. 10 might come into force.

To estimate with any chance of success the effect on wages of a reduction of the hours of labour, we must be furnished with the following data :-

(1) The amount of increase or diminution of the total product of industry.

(2) The amount of increase or diminution of the total number of units of land used in obtaining the product.

(3) The amount of increase or diminution of the average rent of such land.

(4) The amount of increase or diminution of the total amount of capital used in obtaining the product.

(5) The amount of increase or diminution of the average rate of interest on such capital.

(6) The amount of increase or diminution in the 
work of initiation and organisation of industry.

(7) The amount of increase or diminution in the average profits of entrepreneurs.

On (1) depends $x$.

On (2) and (3) depends R.

On (4) and (5) depends I.

On (6) and (7) depends P.

Since $x=\mathrm{R}+\mathrm{I}+\mathrm{P}+\mathrm{W}$

it is plain that to arrive at $\mathrm{W}$, we must inform ourselves as to (1), (2), (3), (4), (5), (6), and (7).

It may be doubted whether even the leaders of the great May demonstrations in Hyde Park have quite realised the complexity of the question with which they are dealing. On 4th May 1890 a quarter of a million of men voted apparently without a qualm of doubt, a resolution on the subject of the reduction of hours of labour prefaced by these words, "That this vast meeting of workers of London, knowing that the excessively long hours of labour being worked in many industries causes irregularity of employment," etc. At the still more imposing demonstration of 1892 the resolution submitted from most of the platforms did not expressly enunciate this point but in the speeches reference was continually made to the fact 
that oue of the reasons of their demands was that men who were now out of work and in want of the necessaries of life, might secure employment. This is a point to which we will shortly return.

$\S 60$. Let us now consider the effect of the action of trades unions and combinations of labour in endeavouring to force wages up. Now those who have followed me thus far will have seen that we can only agree with Fawcett in thinking that under the competitive system the manufacturer is always as powerless to get labourers to work for him at less than the normal wages, as he would be to buy cotton at less than the economic price, if we suppose in the labourer perfect mobility and perfect intelligence as to his own interest. How very far we are from being able to do this, a consideration of the immense gap which divides the knowledge and intelligence of an ordinary labourer from that of the "economic man" is enough to show. In the very common case therefore of a rise of money wages economically justified (for example by a depreciation of the value of gold), the labouring class will in the natural course of things be very much slower to move than the entrepreneurs (the "economic men") will be in a converse state of affairs. By banding their resources and their knowlerge together the working classes 
are vastly assisted in coping with economic situations. I am disposed to think that this is the principal utility in trades unions, but the utility is certainly one of foremost importance.

$\S$ 61. Professor Walker says (Political Economy, part vi. chap. v., "Trades Unions and Strikes," $\S \S 394,395)$ :-

"These associations, though in form opposed to competition, and though subject to many abuses, do yet, in certain states of industrial society, at least assist the labourers as a class to assert their interest in the distribution of the product of industry." . . . " Respecting trades unions, the question is not whether joint action is superior to the individual action of persons enlightened as to their industrial interests, but whether joint action may not be better than the tumultuous action of a mass, each pursuing his individual interest with more or less of ignorance, fear, and passion."

"Now with a body of employers, few, rich, and powerful, having a friendly understanding among themselves, and acting aggressively for the reduction of wages, or the extension of the hours of work, and on the other side, a body of 
labourers, numerous, ignorant, poor, mutually distrustful, while each feels under a terrible necessity to secure employment, else wife and child will starve, who shall say that such a body of labourers might not be better able to resist the destructive pressure from the employing body, if organised and disciplined, with a common purse and with mutual obligations enforced by the public opinion of their class, than if each for himself were to measure strength with his employer?" . . .

"Perfect competition which affords the only absolute security possible for the equitable and beneficial distribution of the products of industry, requires that each and every man for himself should unremittingly scek, and unfailingly find, his best market. If for any reason, whether from physical obstruction or legal inhibition, or from his own poverty or weakness of will or ignorance, or through distrust of his fellows, or a habit of submission to his employer, or his social superiors, any man fails in fact to reject the lower price and to seize the higher price, the rule of competition is, so far as that individual is concerned, violated; the immunity against deep and permanent and 
economic injury which is afforded by competition is lost; the man may be crushed in his spirit, in his health, in his habits of life, and may thus sink finally and hopelessly to a lower industrial grade. The industrial history of mankind is full of examples of large populations thus broken down by the force of competition to which they were unequal, until they have become pauperised, brutalised, and diseased beyond the power of any purely economical causes to raise them upwards and restore them to industrial manhood."

$\S 62$. Professor Walker puts thus forcibly the main part of the case for trades unions, and what he says is accentuated by the fact that many of the leaders of these unions are amongst the most intelligent and earnest of their members. Bearing in mind the aspect of the case he here presents, one is surprised at the unsparing denunciation of other features of the trades-union system which we find in his book on Wages (see his remarks whilst discussing the subject of trades-union rules in the last chapter of The Wages Question). His condemnation is as severe as that of Cairnes (see Cairnes's Leading Prineiples of Political Economy, part ii. chap. iv. $\$ 4$. The writer enforces his case by a quotation from 
Thornton). It is true that in both instances condemnation is called forth by a consideration of the wretched regulations by which many of the unions have from time to time sought to "make work" (or as we should put it in our formulæ, to diminish the product- $x$ ), and when their sins in this respect are summarised in a catalogue of error, the total is disheartening enough.

$\S 63$. But is it not true that this evil, and the still more serious ones of lawlessness and intimidation, some amount of which seem almost inseparable from the union methods of industrial warfare (can we say that they were entirely absent even in the London Dockers' Strike of 1889 ?), sink into insignificance when compared with the immense advantages that have accrued by the exercise of the important functions set forth in the passages quoted above from Professor Walker?

Or putting the same question in other words: Do not the evils which trades unionism has wrought by hampering the action of competition, sink into insignificance by the side of the immense benefits it has brought about by increasing in other ways effective competition?

In the common enough case where $x$ is divided amongst $\mathrm{R}, \mathrm{I}, \mathrm{P}$, and $\mathrm{W}$ in a proportion more favour- 
able to the first three than the economic conditions justify, because the labourer is not intelligent enough, or well informed enough, to insist on his due proportion, trades unions are continually being of the greatest service in placing him in this respect on an equal footing with the entrepreneur.

$\S 64$. But the question now arises, when the economic equilibrium is once attained, is it in the power of labour by combination still further to force wages up?

Suppose our Standard Case No. 1 to represent a state of economic equilibrium, $\mathrm{W}=600$ : can labour by combining together, and agreeing not to work for less than a 10 per cent advance on its former wage, bring it about that $\mathrm{W}$ shall equal 660 ?

As there is no change in conditions that will increase $x$, such an augmentation of $\mathrm{W}$ can only be brought about by a decrease in the sum of $R, I$, and $P$. This aggregate which before amounted to 400 must now be reduced to 340 . As labour refuses to engage itself at the former rate of remuneration, a scarcity of this agent of production in relation to land, capital, and organising power, is produced. These would very likely be content (as they might be in the case of an introduction of the eight hours' day) with remuneration in smaller proportion 
than previously enjoyed, but as in Case No. 8, so now, it does not follow that they will be content with reward lessened to the extent proposed. It is probable that some land, some organising power, and a good deal of capital will be withdrawn from industrial uses in the area affected. No doubt things may adjust themselves to an industrial equilibrium consistent with these diminished amounts of the other agents of production; but it is probable that this will come about only by an employment of a diminished amount of labour. That all the available labour should be employed, was before secured by the process of what is called the "higgling of the market." But labour has expressly excluded itself from this process, and accordingly a certain proportion of it will be stranded high and dry above the highwater mark of the extreme of what will be accorded by the other agents of production. Some of the labourers will be thrown out of employment, and the product of industry"will be lessened.

The case may then probably work out thus :-

Case No. 1.

Standard Year.
Case No. 11.

Labour agrees to combine, and to demand a 10 per cent advance on former wage. 
10 numerical Units of Labour supply 10 Units of Labour Power.

$$
x=1000 \text {. }
$$

10 Units of Labour Power

$$
\begin{aligned}
& W=10 \times 60=600 \\
& R+I+P \quad=400 \\
& 1000
\end{aligned}
$$

10 numerical Units of Labour, 1 unit of which is thrown out of employment, supply 9 Units of Labour Power.

Assuming variation of Product proportionate to the numerical Units of Population actually in employment, ${ }^{1}$

$$
x=900 \text {. }
$$

9 Units of Labour Power

$$
\begin{aligned}
& \text { W }=9 \times 66=594 \\
& \mathrm{R}+\mathrm{I}+\mathrm{P}=306^{1} \\
& \mathrm{I} \text { N.B.-If } \mathrm{R}+\mathrm{I}+\mathrm{P} \text { do not } \\
& \text { equal 306, the assumption of } \\
& \text { variation of product propor- } \\
& \text { tionate to the Units of Labour } \\
& \text { Power will not be justified, and } \\
& x \text { will equal either more or } \\
& \text { less than 900. For example if } \\
& \text { Land, Capital, and Organising } \\
& \text { Power were affeeted as in Case } \\
& \text { No. } 8 \text { then } \mathrm{R}+\mathrm{I}+\mathrm{P} \text { would equal } \\
& 317 \text { and } x \text { would equal } 911 \text {. }
\end{aligned}
$$

To arrive at the average wage received by the labourer in the new circumstances we must not simply take into account the wage-receiving labourers. Of them there are 9 units ; $594 \div 9=66$, giving an increase of wage from 60 to 66 or 10 per cent (by the supposed conditions of the case they 
would not work for less). But there are the unemployed labourers to be reckoned with. They will not rest content to remain idle, and to abstain from underbidding the others for employment, unless they are united with them in a combination the funds of which will give them their share of $\mathrm{W}$. To find the average wages received by a numerical unit of labourers then, we must divide 594 not by 9 but by 10 , giving us $59 \frac{2}{5}$ or a diminution of wage in the proportion of 60 to $59 \frac{2}{5}$.

To sum up the results then, the capitalists have had to reinvest part of their capital, the landlords and the entrepreneurs have suffered monetarily severely; the labourers have suffered monetarily slightly, but morally they are likely to suffer severely from a proportion of their number being thrown into compulsory idleness. Practically it is hardly conceivable that a combination of men would hold together for any length of time under such conditions.

$\S 65$. But just as we found that under the eight hours' regime variations of Case No. 8 were conceivable, the first of which (Case No. 9) made the acquisition of leisure a positive monetary benefit to the labourers, and the second of which (Case No. 10) made the acquisition of leisure, dearer proportion- 
ately, than before,-so it is conceivable that the average remuneration of labour would be positively increased by a combination such as we have supposed, to force up wages; or again we may imagine circumstances under which the average remuneration of labour would be affected more unfavourably than has been depicted in Case No. 11.

It is unlikely that the first result would be attained unless the new forms that industry took were such as employed more fixed capital, etc. And it is on the face of it improbable that a lower rate of remuneration to $\mathrm{R}, \mathrm{I}$, and $\mathrm{P}$ should bring into industrial use a larger amount of land, capital, or organising power. It is not however an impossible case. Dear labour might result in the adoption of expensive machinery, so that some of that labour might be dispensed with; and it is conceivable that by the employment of much more fixed capital, and more organising power, $x$ would not be diminished, but increased; it is even possible that a greater development of the industry would take place, and that all the labourers might again be employed at the 10 per cent increase of wage, and all would be well that ended well just as in Case No. 9.

But in the very improbable case of a diminished employment of labour, combined with an increased 
wage per numerical unit of labour (whether the product of industry be diminished or not), although the result appears somewhat like that of Case No. 9, it is not one for like congratulation. In Case No. 9 the men had improved their monetary position, and they enjoyed increased leisure all round. In the case now supposed they would improve their monetary position, but most of them would have as much work as before, whilst a section of them would remain entirely idle.

$\S 66$. This then leads us to the proposed diminution of the hours of labour as a remedy for irregularity of employment. In the above case it very naturally occurs to the mind that by making a further agreement to average the hours of work amongst the total number of the labour combination, the case is made exactly analogous with Case No. 9 . First you must force up wages, by a combination, till the average per capita (taking into account unemployed as well as employed) is higher than before. Then you must equalise work by the nine, the eight, the seven hours' regulations. This is the remedy for the labour problem believed in by the half million of people in Hyde Park. We have been able to conceive circumstances in which it would actually become operative, but the circumstances depend 
upon data which are positively essential to the case, and far indeed from being as certain of realisation as the Hyde Park demonstrators assume. What are these data?

(1) That with the increased cost of labour there will either be an increase of $x$ of more than the like amount, or a diminution of $\mathrm{R}+\mathrm{I}+\mathrm{P}$ by more than the like amount, or that it shall be more than made good by a combination of the two.

(2) That labour will remain so self-organised, constant, and faithful, as in the first place to maintain the higher rate of wage (during which time the unemployed must abstain from underbidding the employed), and in the second place to adhere to the prescribed hours of labour (during this time the employed must refuse to work longer than certain hours).

(3) That if the economic conditions have so far proved favourable, they will not be rendered unfavourable by the waste entailed in the conversion of labour of a certain standard of length per day to a shorter standard. This waste will principally consist in teaching the necessary technical knowledge to a larger number, and in the fact that the increase in the number will 
probably be drawn from those who have least natural and acquired ability for work, so that the average efficiency of labour for a certain number of hours will probably be higher if it is done by 100 men than by 120 . It is likely that this will prove to be a more important consideration than that which has to be put against it, viz., that the same individuals will do more efficient work per hour during eight hours, than they will during ten. Putting it in another way when there is a residuum of unemployed, that residuum consists of the least able workmen, and if by an eight hours' movement they are taken into employment, the average efficiency of labour is reduced, and may be reduced to an extent that will prevent hopes from fructifying that might otherwise be realised.

$\S 67$. So much for action initiated by a combination amongst the labourers; now let us examine the effect of action initiated by the entrepreneur.

Suppose Case No. 1 to represent a state of economic equilibrium in a large concern. The entrepreneur determines to introduce a system of profitsharing. He says to his men : "Now I will pay you in addition to your former wage $\frac{1}{10}$ of the product 
of industry. Numerous cases are quoted (see Mr. Sedley Taylor's and Mr. Gilman's books on profitsharing), where such an arrangement has led to monetary benefit not only to the workman, but also to the entrepreneur. As we may presume that $R$ and $I$ do not diminish, such a result can only be explained by an increase in $x$ greater than the promised increase in W. This is accounted for by the increased efficiency of the workman consequent on the enthusiasm generated by a prospect of higher reward, directly dependent on his own efforts.

Case No. 1.

Standard Year.

$$
\begin{aligned}
x & =\underline{1000} \\
\mathrm{~W} & =\mathbf{6 0 0} \\
\mathrm{R} & =80 \\
\mathrm{I} & =160 \\
\mathrm{P} & =\frac{160}{1000}
\end{aligned}
$$

Case No. 12.

Profit-sharing introduced.

$$
\begin{array}{rr}
x= & =\frac{1120}{\mathrm{~W}}=712 \\
\mathrm{R} & =80 \\
\mathrm{I} & =160 \\
\mathrm{P} & =168 \\
& \frac{1120}{1120}
\end{array}
$$

We observe here that whilst $R$ and $I$ remain constant the monetary position of the labourer is improved in the ratio of 600 to 712 , and that of the entrepreneur in the less ratio of 160 to 168 .

It so happens in the example that we have taken, that whilst the ratio of $\mathrm{W}$ to the whole product 
has been increased that of $\mathrm{P}$ has been diminished. Now it is conceivable that a prospect of $\frac{180}{1000}$ of the product of industry will serve to induce entrepreneurs to initiate industry, but that a reward of $\frac{168}{1120}$ which equals only $\frac{150}{1000}$ of the total product, will not; but it is conceivable only if they consider that the increased product will entail on their parts an increased expenditure of their powers, energies, and diligence. If it can be shown that the increased product accrues without any further tax being placed upon them (and indeed the tendency would be the other way, for less supervision would be required, and there would be less mental care involved), they would gladly accept any absolute increase of their share of the product, even though relatively to the whole product it might lave decreased.

If entrepreneurs generally became convinced that like measures initiated by themselves would bring about like results, there would be a general change in the economic equilibrium, and the new state of things would be better both for workmen and entrepreneurs, than the old.

$\S 68$. The exact point where equilibrium would be regained would be that where the increase of product exceeded to the greatest extent the promised increase of reward to labour. Thus in Case No. 12 
the increase of product equals $\frac{120}{1000}$ of $x$. The increased reward to labour equals $\frac{112}{1000}$ of $x$. The former exceeds the latter by $\frac{8}{1000}$ of $x$. If it was found that with a promised share of $\frac{1}{11}$ of $x$, the increase of $x$ exceeded by 6 units the increased reward of labour, whereas with a promised share of $\frac{1}{9}$ of $x$, the increase of $x$ exceeded by 10 units the increased reward of labour, the tendency to economic equilibrium would dictate a larger share of the product being assigned to labour; and vice versa if the fact of assigning an increased proportion of the product to labour resulted in the increase of the product itself exceeding to a less extent the increase in the reward of labour.

So much for profit-sharing that "pays" (i.e. pays the entrepreneur to whose initiative it is due). Now let us suppose a case of profit-sharing which does not pay in this sense.

$\S 69$. As before, an increase of wage equal to $\frac{7}{10}$ of $x$ is promised, but the resulting efficiency in labour is not quite so good as supposed in Case No. 12 :-

Case No. 1.

Standard Year.
Case No. 13.

Profit-sharing which does not pay so far as the Entrepreneur is concerned. 


$\begin{array}{rlrl}x & =\underline{1000} & x & =\underline{1100} \\ \mathrm{~W} & =600 & \mathrm{~W} & =710 \\ \mathrm{R} & =80 & \mathrm{R} & =80 \\ \mathrm{I} & =160 & \mathrm{I} & =160 \\ \mathrm{P} & =\underline{160} & \mathrm{P} & =\underline{150} \\ & \underline{1000} & \end{array}$

The monetary position of the labourer is improved in almost the same ratio as in Case No. 12, but that of the entrepreneur is injured. He however has the satisfaction of seeing an increased amount of prosperity amongst his workpeople, which is greater than the decrease of prosperity to himself (in the case supposed, elevenfold greater). In Case No. 12 the example set by the entrepreneur who initiates profit-sharing is one that will be followed alike by those under the sway of purely economic, and those influenced by ethical motives. In Case No. 13 those only whose economic instincts are tempered by ethical considerations will be likely to follow the lead. But for these it is a strong case. It is like an appeal to a man to give $£ 100$ to a hospital, on the grounds that by so doing he will make available for the same purpose a further sum of $£ 1000$. It is very distinctly a way of helping towards the more equal distribution of wealth, and it is an educative process; it helps those who are 
low down on the economic ladder to rise by their own endeavours.

The objections to profit-sharing are summarised in an interesting article by Professor W. J. Ashley in the Economic Review for July 1892 ("Methods of Industrial Peace "). They are however to my mind inconclusive. He objects firstly that it does not meet the difficulty of determining the ordinary wage (to which the profit-share is to be added). This is quite true, but are we to object to a system that does one good thing, because it does not do another separate and distinct good thing? If a system of profit-sharing is entered upon in order to defeat the trades unions it is likely to be, and deserves to be, a failure; but as a supplement to the action of the unions it seems to me capable of being very useful. The main wage-bargain will be struck with the uuion ; profit-sharing will provide for the creation of an additional wage. The other objection that profits are often "made in the counting-house, rather than in the workshop," is doubtless cogent in a great many businesses; where, and to the extent to which, it is valid, it is of course a reason for not adopting the profit-sharing scheme. This has been fully recognised by, for instance, such a strong advocate of the scheme as Mr. Gilman; but there remain 
a large number of businesses in which the determination of profits does not rest mainly with the counting-house, in which increased industry, ingenuity, and conscientiousness on the part of the workmen will leave a mark on profits which will be perceptible.

$\S 70$. Now contrast Case No. 13 with a case in which a philanthropic employer determines to place his workmen in a similar position, but in order to do so, instead of instigating them to better work by a system of "payments by results," he at the end of the year simply presents them with a bonus out of the profits :-

Case No. 13.

Profit-sharing which does not pay so far as the Entrepreneur is concerned.
Case No. 14.

The philanthropic employer distributes a bonus amongst his employés equal to their increase of wage in Case No. 13.

$$
\begin{aligned}
x= & =-1100 \\
\mathrm{~W} & =710 \\
\mathrm{R} & =80 \\
\mathrm{I} & =160 \\
\mathrm{P} & =\frac{150}{1100}
\end{aligned}
$$

$$
\begin{array}{r}
x=1000 \\
W=-710 \\
R=80 \\
I=160 \\
P=\frac{50}{1000}
\end{array}
$$

The monetary position of the labourer is the 
same as in Case No. 13, but the profits of the entrepreneur are diminished by two-thirds. Evidently the example is not likely to be nearly so widely followed as that of the employer in Case No. 13, nor is it as likely to be perpetuated by the successors to the headship in the particular industrial affair concerned. For in the first place, the entrepreneur does not in proportion to his sacrifice secure nearly as important gain for his workpeople, and in the second place many entrepreneurs who could afford the sacrifice supposed in Case No. 13 could not afford that supposed in Case No. 14. I am inclined to think that even on ethical grounds it would not be a good thing if the example set in No. 14 were extensively followed, tending as it would do, to reward work out of proportion to the benefit it conferred on the community. This objection would not hold, or would hold only to a very slight extent, with Case No. 13, if we suppose that the bulk of the increased wage arises not from a sacrifice on the part of the entrepreneur, but that it is consequent on greater efficiency of labour.

Reward of labour greatly out of proportion to its efficiency is a demoralising influence because it is opposed to the mobility of labour, and tends to attach people to work for which they are less fitted 
than what they might be doing. But an increased reward of labour which causes it to become much more efficient is an eminently educative and moralising influence, tending to increase the intelligence, skill, industry, and honour of the workman, and also his mobility.

In connection with Cases Nos. 12, 13, and 14, we have observed the importance of the question of how far such systems initiated by individual entrepreneurs are likely to be generally imitated.

$\S 71$. The further question arises how far the employed class would be able to compel unwilling employers to adopt such methods. In Case No. 12 they would merely be demanding a state of economic equilibrium, and they could attain their object by a strike without any after results arising which would counteract the direct benefit attained. The granting of their demand would not result in a state of things which would tend to the withdrawal of any part of the land, of the capital, or of the organising power required for the industrial processes.

In Case No. 13 any attempt to compel entrepreneurs generally to surrender such a portion of their profits as the particular entrepreneur 
in the case supposed has voluntarily given up, might result in the withdrawal of some of the necessary organising power, and we should have a case analogous to Case No. 11, where some of the labourers are thrown out of employment.

The same considerations apply, but with considerably more force, to Case No. 14.

It is however fair to remark that such conduct as is supposed on the part of the entrepreneurs in Cases Nos. 13 and 14, would tend to put labour very much on the qui vive, and that it would be less likely than would otherwise be the case to allow itself to be depressed in any way more than the economic situation justified. The danger indeed would be that it would demand more than was justified by the economic situation; this it might temporarily even attain, because of the inmobility of fixed capital etc., but in the long run we should have results similar to those in Case No. 11, and labour would be thrown out of employment.

$\S 72$. It will be observed that the theory set forth in the foregoing pages sets at nought the so-called "Iron Law of Wages." Wage has been treated as something dependent on a service rendered to the community, entirely irrespective of the position of the wage-receiver. 
But the "Iron Law of Wages" cannot be altogether ignored; it is not alone in the pages of Lassalle that we are confronted with it; reference to it, or something very like it, is for example made in the publications of so orthodox a body (orthodox that is to say in respect to its economic theories) as the Charity Organisation Society. Thus in one of the pamphlets issued by that body, entitled "Outdoor Relief" (1890), I read as follows :-

"It cannot be denied that the low wages of women are caused to some extent by the out-relief system. Thus, for instance, if outrelief is given to a woman who gains her living by charing or taking charge of chambers, her employer is able to take into account what she receives from the rates, and to fix her wages accordingly."

Now I have no desire to deny that this may be so. The theory of wages I have attempted to set forth, is applicable only to "economic" men and women. I submit indeed that the fact that a woman receives help from the rates (except under particular circumstances such as those commented upon in $\S 73$ ) makes no difference at all to her economic position as a wage-earner; that is to say, that if she, and those in like position to herself, 
chose, they could enforce a rate of wages as high as if they had no such help; and the same is true of those whose wages are eked out by subsidiary industries, such as straw-plaiting and the like. It is however extremely probable, that without combination they would not be sufficiently informed, nor would they act sufficiently in concert to enforce the rights with which the economic position endows them. Hence as I insisted above $(\S 60)$ the extreme importance of trades unions. Very large classes of men now enjoy the full rights that the economic position of the moment affords them; very large classes of women do not; and no doubt till a system of trades unions becomes as complete amongst women as it is amongst men, and amongst men engaged in unskilled labour as it is amongst men engaged in skilled labour, the influence of something like an Iron Law of Wages will be felt amongst the labour of women and of unskilled men-labourers. In these departments of labour the contention that the "standard of living" of the wage-earners influences the scale of wages paid, will find some substantiation.

In order that the advantages of an economic position may be seized, some sort of uniformity of conduct is required amongst those who are entitled 
to reap them. Shopkeepers in the same town are able to sell approximately at the same prices from their knowledge of the economic position; but if a bankrupt stock is sold in their midst at prices below those justified by that position, they are for the moment deprived of their share of trade, in cousequence of the breach in uniformity of action. Mechanics have considerably less individual knowledge of the advantages to be secured from the economic position than shopkeepers, but in combination they. share with each other what knowledge they possess, so that in their unions they are as well informed as the tradesmen.

But the unorganised "uneconomic" man or woman, has neither the first-hand knowledge of the employer or shopkeeper, nor the second-hand knowledge of the member of the trades union. How is uniformity of action to be established here? The readiest way is by hunger to which all men are susceptible, or at all events by a reduction to the minimum which the "standard of comfort" of the period, and of the class involved, allows.

Thus then we see that though the Iron Law of Wages has no place in a theory of wages applicable to "economic" men and women, for those who are unable to grasp the full privileges which the 
economic position justifies, it has a very real meaning, though one much more limited in its application, than Lassalle assumes.

$\S 73$. I stated above that, ordinarily speaking, help from the rates made no difference in the real economic position of the wage-earner. But any contribution to the wage-earner's pocket-constantly incidental to a particular employment will of course affect the wages of that employment, for from the wageearner's point of view such contributions are indistinguishable from wage; in his estimate of the advantages of a given position they will be taken into account as certainly as the nominal wages, so that such contributions practically make a part of wages. The waiter who in a certain restaurant receives $3 s$. a day in "tips," will be willing to accept the post for $18 s$. or $21 s$. a week less wages than he otherwise would do.

It is on record that in certain agricultural districts poor law relief has been known to be administered by a compact body of gentlemen identified with the farming interest, who have systematically given aid out of the rates during several months of the year to able-bodied agricultural labourers. These same gentlemen, acting not in their capacity of Guardians of the Poor (and pre- 
sumably of the public purse) but in that of employers, have found that they have been able to employ farm labourers at a lower rate of wages, taking the year all round, than have farmers living in a less favoured union.

But it will readily be seen that these are not in reality instances of the operation of the "Iron Law of Wages." 



\section{THE LIBRARY \\ UNIVERSITY OF CALIFORNIA \\ Santa Barbara}

\section{THIS BOOK IS DUE ON THE LAST DATE STAMPED BELOW.}


$\frac{d 2+c t}{65}$

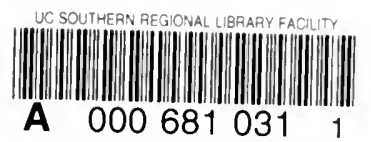


